\title{
Relevance of laboratory testing for the diagnosis of primary immunodeficiencies: a review of case-based examples of selected immunodeficiencies
}

Roshini S Abraham

\begin{abstract}
The field of primary immunodeficiencies (PIDs) is one of several in the area of clinical immunology that has not been static, but rather has shown exponential growth due to enhanced physician, scientist and patient education and awareness, leading to identification of new diseases, new molecular diagnoses of existing clinical phenotypes, broadening of the spectrum of clinical and phenotypic presentations associated with a single or related gene defects, increased bioinformatics resources, and utilization of advanced diagnostic technology and methodology for disease diagnosis and management resulting in improved outcomes and survival. There are currently over 200 PIDs with at least 170 associated genetic defects identified, with several of these being reported in recent years. The enormous clinical and immunological heterogeneity in the PIDs makes diagnosis challenging, but there is no doubt that early and accurate diagnosis facilitates prompt intervention leading to decreased morbidity and mortality. Diagnosis of PIDs often requires correlation of data obtained from clinical and radiological findings with laboratory immunological analyses and genetic testing. The field of laboratory diagnostic immunology is also rapidly burgeoning, both in terms of novel technologies and applications, and knowledge of human immunology. Over the years, the classification of PIDs has been primarily based on the immunological defect(s) ("immunophenotype") with the relatively recent addition of genotype, though there are clinical classifications as well. There can be substantial overlap in terms of the broad immunophenotype and clinical features between PIDs, and therefore, it is relevant to refine, at a cellular and molecular level, unique immunological defects that allow for a specific and accurate diagnosis. The diagnostic testing armamentarium for PID includes flow cytometry - phenotyping and functional, cellular and molecular assays, protein analysis, and mutation identification by gene sequencing. The complexity and diversity of the laboratory diagnosis of PIDs necessitates many of the above-mentioned tests being performed in highly specialized reference laboratories. Despite these restrictions, there remains an urgent need for improved standardization and optimization of phenotypic and functional flow cytometry and protein-specific assays. A key component in the interpretation of immunological assays is the comparison of patient data to that obtained in a statistically-robust manner from age and gender-matched healthy donors. This review highlights a few of the laboratory assays available for the diagnostic work-up of broad categories of PIDs, based on immunophenotyping, followed by examples of disease-specific testing.
\end{abstract}

Correspondence: abraham.roshini@mayo.edu

Department of Laboratory Medicine and Pathology, Mayo Clinic, Rochester, MN, USA 


\section{Introduction and Outline}

Since the topic of primary immunodeficiencies (PIDs) and the associated diagnostic testing is exhaustive and highly complex [1], this review article will focus primarily on 2 key methodologies used for the laboratory diagnosis of PIDs - flow cytometry and genetic testing, by offering case-based examples.

The hallmark of most PIDs is susceptibility to recurrent and life-threatening infections, since the cardinal role of the immune system is host defense. However, the clinical spectrum of PIDs is very diverse and can include other manifestations such as autoimmunity, neoplasia, and congenital anomalies of organs and/or skeleton. Therefore, the traditional role of the laboratory has been to provide supportive data to a largely clinical, radiological and family history-based diagnostic approach. The development of reagents capable of identifying disease-specific mutated proteins along with the ability to evaluate multiple subsets of immune cells and their function, such as respiratory burst, proliferation or phosphorylation, simultaneously, facilitated the incorporation of multi-color and functional flow cytometry into the diagnostic work-up for PIDs.

While flow cytometry may be diagnostic for many PIDs where specific proteins and/or defective function can be directly assessed (Table 1) [2-4], the relevance of confirming the diagnosis by genetic testing or mutation analysis still remains germane, $[5,6]$ especially when protein is present but non-functional. Further, genetic testing can provide a venue for genetic counseling by aiding in the identification of carriers, particularly for X-linked diseases, as well as enabling prenatal diagnosis. It is particularly helpful in elucidating the correlation between phenotype and genotype, when there are either allelic variants or unusual presentations present, leading to prognostic insights. But, surpassing all these is the role of genetic testing in identifying asymptomatic individuals who carry a defective gene associated with a potentially lethal PID, prior to clinical and/or other immunological manifestations of disease, facilitating early therapeutic intervention, and this is exemplified by the newborn screening program for severe combined

Table 1 List of only those PIDs where screening diagnosis can be made by specific protein detection by flow cytometry

\begin{tabular}{|c|c|}
\hline PID & Disease-specific protein detected by flow* \\
\hline X-linked agammaglobulinemia (XLA) & Bruton's tyrosine kinase (Btk) in monocytes, platelets \\
\hline $\begin{array}{l}\text { Wiskott-Aldrich syndrome (WAS) and related allelic variants, X-linked thrombocytopenia } \\
\qquad(\mathrm{XLT}) \text { and X-linked neutropenia/myelodysplasia }\end{array}$ & Wiskott-Aldrich Syndrome protein (WASP) \\
\hline X-linked Hyper IgM syndrome (XL-HIGM) & CD40L (CD154) on activated T cells \\
\hline Hyper IgM syndrome type 3 & CD40 on B cells and/or monocytes \\
\hline CVID-associated defects & ICOS (activated T cells), CD19, BAFF-R, TACI \\
\hline Familial Hemophagocytic Lymphohistiocytosis (fHLH) & Perforin in NK cells and CD8 T cells \\
\hline X-linked lymphoproliferative disease (XLP) & SAP $(\mathrm{SH} 2 \mathrm{D} 1 \mathrm{~A})$ \\
\hline X-linked inhibitor of apoptosis (XLP2) disease & XIAP (BIRC4) \\
\hline Chronic Granulomatous disease (CGD) - Autosomal recessive & p47phox, p67phox, p22phox in neutrophils \\
\hline Leukocyte Adhesion deficiency type 1 (LAD-1) & CD18, CD11a, CD11b on leukocytes \\
\hline Leukocyte Adhesion deficiency type 2 (LAD-2) & CD15 (Sialyl-Lewis ${ }^{X}$ ) on neutrophils and monocytes \\
\hline Interferon gamma receptor 1 deficiency & IFNyR1 \\
\hline Interferon gamma receptor 2 deficiency & IFNyR2 \\
\hline IL-12 and IL-23 receptor $\beta 1$ deficiency & $\mid L-12 R \beta 1$ \\
\hline STAT1 deficiency & pSTAT1 \\
\hline STAT5B deficiency & pSTAT5 \\
\hline Immunodeficiency, enteropathy, X-linked (IPEX) & FOXP3 on regulatory T cells (Tregs, CD4+CD25+FOXP3+) \\
\hline Warts, Hypogammaglobulinemia, and myelokathexis (WHIM) & CXCR4 on T cells \\
\hline Common gamma chain ( $c \gamma$ chain) & $\begin{array}{c}\text { CD132 (IL-2RG, IL-4RG, IL-7RG, IL-9RG, IL-15RG) on } \\
\text { activated T cells }\end{array}$ \\
\hline Bare Lymphocyte Syndrome type I and II (BLS I and II) & $\begin{array}{c}\text { MHC class I and II expression on monocytes, B cells and } \\
\text { T cells (activated) respectively }\end{array}$ \\
\hline CD25 deficiency (IPEX-like syndrome) & CD25 (IL2R $\alpha)$ \\
\hline Membrane cofactor protein (MCP) deficiency & CD46 \\
\hline Membrane attack complex deficiency (MAC) & CD59 \\
\hline
\end{tabular}

*Presence of protein as detected by flow cytometry does not rule out an underlying functional mutation, therefore, results have to be correlated with other laboratory and immunological parameters, including functional flow cytometry when applicable, clinical and family history and confirmed by genetic testing for final diagnosis. Details of these individual defects can be found in "Immunologic Disorders in Infants and Children, $5^{\text {th }}$ Ed, Eds. R. Stiehm, H. Ochs and J. Winkelstein, 2005, Elsevier Saunders). 
immunodeficiencies (SCID) and T cell lymphopenia (discussed later in this review). The enaction of federal legislation (GINA 2008, Genetic Information Nondiscrimination Act) now protects patients who obtain genetic testing from any form of financial, health or other discrimination, facilitating implementation of diagnostic genetic testing when appropriate [7].

The classification of PIDs has been primarily based on the chief component(s) of the immune system affected resulting in at least 8 broad categories - combined $T$ and $\mathrm{B}$ cell, predominant antibody, well-defined PIDs, immune dysregulation, phagocyte-associated, innate immunity, autoinflammatory, and complement defects [8]. But, these categories are by no means exclusive and there can be considerable clinical and immunological overlap between them. There are other approaches to classification [9], which can include immunophenotyping for specific PIDs, as will be discussed later in this review.

To limit the scope of this review, the following PIDs will be used as examples for the laboratory diagnostic work-up: X-linked agammaglobulinemia (XLA), Chronic Granulomatous Disease (CGD), and Wiskott - Aldrich syndrome (WAS)/X-linked thrombocytopenia (XLT).

\section{Case 1}

A 51 year old male presents to an adult immunodeficiency clinic for evaluation of a life-long history of recurrent sinopulmonary infections. Diagnostic work-up done elsewhere at a prior evaluation revealed profound hypogammaglobulinemia (IgG, IgA and IgM) for which he was initiated on intravenous immunoglobulin (IVIG) at the age of 28 years, but he was never given a clear diagnosis of the underlying medical problem. On his recent visit to the above-mentioned immunodeficiency clinic, an immunologic assessment was performed, which included lymphocyte subset quantitation, immunoglobulin levels along with documentation of clinical history. Not surprisingly, the IgG levels were within normal range (due to the IVIG) but the IgA and IgM were undetectable. The flow cytometric quantitation of $\mathrm{T}, \mathrm{B}$ and NK cells were significant for an almost complete absence of CD19+ (and CD20+) B cells (0\%, 2 cells/uL). No pertinent family history was obtained from the patient and the patient was given a diagnosis of Common Variable Immunodeficiency (CVID). Management of the patient was essentially unchanged since the patient was already receiving replacement immunoglobulin therapy, and prophylactic versus therapeutic use of antibiotics was discussed.

The case was referred to a laboratory immunologist to determine if the diagnosis of CVID was indeed accurate for this patient. Based on the clinical history of life-long recurrent infections, male gender, very low levels of immunoglobulins and nearly absent B cells, the differential diagnosis should have also included X-linked agammaglobulinemia (XLA), despite the age of the patient ( $5^{\text {th }}$ decade of life).

Laboratory testing was undertaken to evaluate for Bruton's tyrosine kinase (Btk) protein, typically present intracellularly in monocytes, B cells and platelets. Intracellular flow cytometry was performed on B cells and monocytes of a healthy control and monocytes from the patient (since B cells were absent) (Figure 1A and 1B). The analysis revealed normal expression of Btk protein within the monocytes from the patient. However, since certain mutations can permit protein expression while abrogating function, it is important to follow protein analysis with genotyping. Full-gene sequencing (which refers to the sequencing of the entire coding region of the gene with intron-exon boundaries and the 5' and 3' untranslated regions -UTRs) revealed a nonsense mutation, W588X in exon 18 (old nomenclature; exon 17 - new nomenclature since the first exon of the $B T K$ gene is non-coding) of the $B T K$ gene, which contributes to the kinase domain in the protein (Figure 1C). This mutation resulted in premature truncation of the protein (loss of 72 amino acids from the 3' end of the kinase domain), which permitted intracellular protein expression but affection function of the protein (Figure 1D).

This additional laboratory analysis allowed a correct diagnosis of XLA to be provided to this patient, which in this case did not change medical management (use of IVIG) but provided a venue for discussing the significance of monogenic defects, such as XLA and appropriate genetic counseling for at-risk family members, such as carrier offspring.

To date, a total of 7 patients, including this patient have been identified as having this particular mutation within the $B T K$ gene.

The $B T K$ gene has 19 exons, 18 of which are coding and to date, over 600 mutations have been described within this gene as being associated with the clinical phenotype of XLA.

XLA is a primary B-cell deficiency [10] characterized by recurrent respiratory or gastrointestinal tract infections, usually within the first year of life, though the above case exemplifies that a diagnosis may not be made till much later in adult life, even if appropriate treatment is empirically initiated based on infectious history, immunoglobulin levels and absence of vaccine-specific antibody responses. Besides the hypogammaglobulinemia, absence or dramatic reduction in the number of circulating $B$ cells is another hallmark of this disease, because the Btk protein is critical for B cell development within the bone marrow and maturation in the periphery (Figure 1E).

XLA can often be misdiagnosed as CVID in adults because of overlapping features, such as hypogammaglobulinemia and recurrent infections. However, only $5 \%$ of 


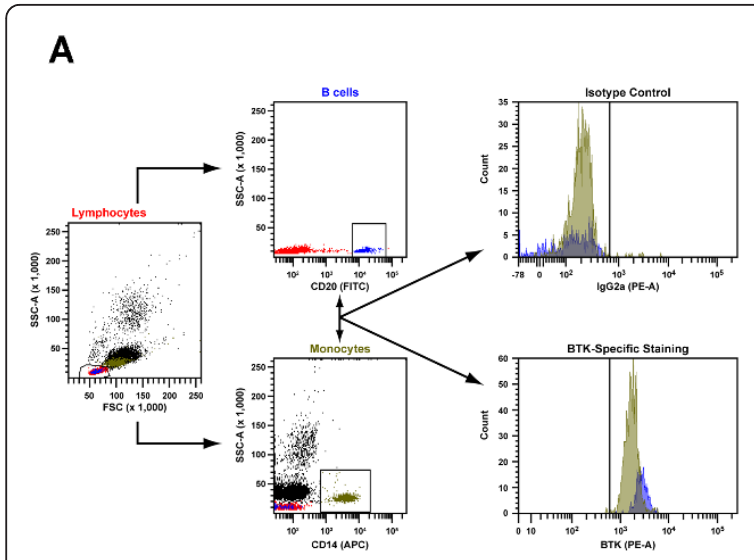

B

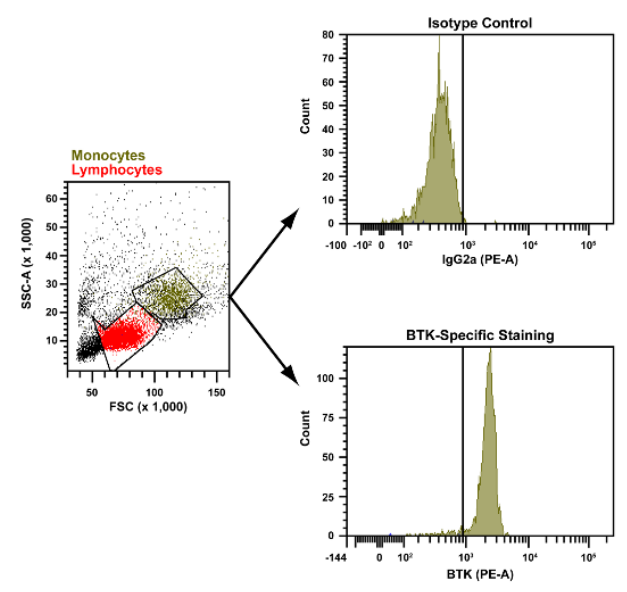

C

A

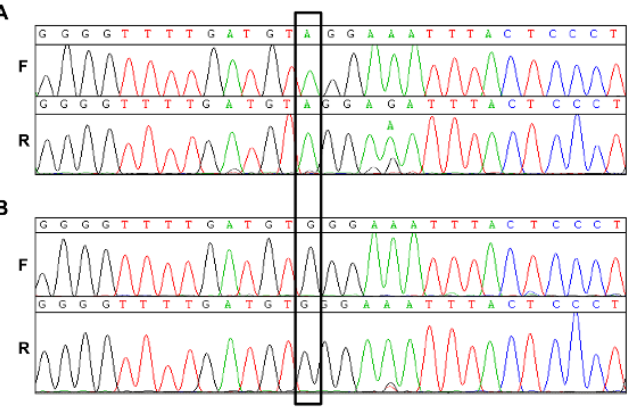

D

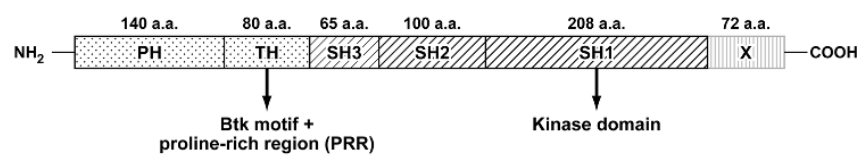

E

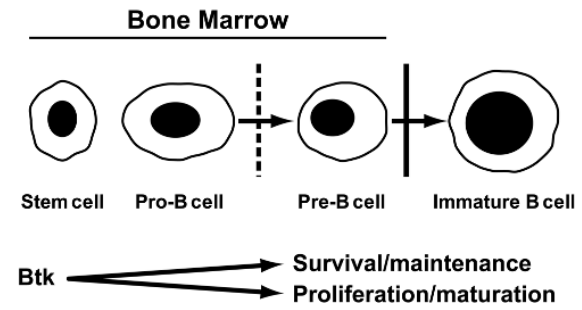

Figure 1 Evaluation for X-linked agammaglobulinemia (XLA). A) Flow cytometric evaluation for Btk protein in a healthy control. B) Flow cytometric evaluation for Btk protein in Case 1 patient. C) Full-gene sequencing in the BTK gene for mutation analysis in Case 1 patient. D) Schematic representation of Btk protein structural organization. E) Schematic representation of Btk in B cell development.

CVID cases have less than $1 \%$ of peripheral CD19+ B cells [11]. Hypoplasia of secondary lymphoid tissue, such as tonsils, adenoids and lymph nodes can be helpful in adults to confirm a presumptive diagnosis, however, this feature is not useful in newborns and very young infants as the hypoplasia may not be apparent due to the lack of antigen-driven expansion of $B$ cells at that age.

Therefore, XLA should be in the differential diagnosis of a male patient who presents with recurrent sino-pulmonary infections, profound hypogammaglobulinemia of the 3 major isotypes, absent or decreased peripheral B cells, neutropenia, Giardia-associated diarrhea, sepsis, meningitis or encephalitis with absent or hypoplastic lymphoid structures. The susceptibility of XLA patients to bacterial and enteroviral (single-stranded RNA viruses) infections may be related to defective Toll-like receptor (TLR) signaling in dendritic cells (DCs) in patients with XLA $[12,13]$, though TLR signaling and downstream effector functions in neutrophils have been shown to be normal [14].

There can be considerable phenotypic heterogeneity including age of presentation depending on the nature and location of the mutation within the gene [15]. In a study of 201 US patients with XLA, it was determined that infection was the dominant clinical presentation, though in a small proportion of patients, family history was the initial presentation. A quarter of these patients had both infection and family history, and smaller numbers also had neutropenia [16]. The diagnostic criteria included a positive family history, absent B cells and hypogammaglobulinemia and identification of mutations within the BTK gene [16].

Laboratory testing is available in larger reference laboratories for flow cytometric-based evaluation of Btk protein $[17,18]$ and full-gene or known mutation sequencing. It is critical to perform a complete evaluation, including genetic testing since there is a large 
spectrum of variability in the phenotype depending on the nature of the specific BTK mutation $[15,19,20]$ and this would be relevant for future genetic testing and counseling as well as genotype-phenotype correlations.

For genetic counseling purposes, if a female individual has one affected male child and any other affected male relative, then she should be regarded as an obligate carrier. Approximately half (50\%) of male XLA patients do not have family history of the disease, and therefore, either have a de novo or spontaneous mutation ( $15-20 \%$ of patients) or the mother is a carrier of the mutation (majority of cases, 80-85\%). All the female offspring of an affected male patient will be obligate carriers of the mutation. While carrier females for X-linked diseases can usually be identified by flow cytometry due to random $\mathrm{X}$-chromosome inactivation resulting in two populations for the protein being tested, there are some individuals who can be missed when the specific mutation permits Btk protein expression, and therefore, genetic testing is the most robust method for identifying carriers. Typically, the familial disease-causing mutation should be known for carrier genetic testing for at-risk female relatives, or asymptomatic male infants of carrier females, and for prenatal diagnostic testing. It is possible to perform full-gene sequencing in carriers if the specific disease-causing mutation is not known, however, if a novel mutation is identified in the female carrier, it would require clinico-pathological correlation and identification of the same mutation in affected male relatives to establish its clinical significance. Prenatal diagnosis in a male fetus $(46, \mathrm{XY})$ requires prior knowledge of the disease-causing mutation.

\section{Case 2}

A 46 year old male presented to the Nephrology Clinic within a large Transplant Center for evaluation related to the need for a third renal transplant. His prior history was significant for bloody, persistent diarrhea in childhood and he was later on shown to have thrombocytopenia. He also had a history of eczema in childhood, which resolved over time. His childhood and early adulthood was otherwise uneventful with no significant bleeding history, but there was occasional minor bruising. The history was notable for lack of recurrent infections in childhood or early adult life. Twelve years prior to this presentation, he was found to have evidence of chronic renal disease, secondary to glomerulonephritis and as a result also developed hypertension. Three years following the discovery of chronic renal failure, he received a living related donor renal transplant with no evidence of acute rejection episodes. However, two years post-transplant, there was pathologic and clinical evidence of chronic allograft nephropathy with BK viremia, indicating likely BK virus (BKV)-associated nephropathy.
Two years following the identification of BK nephropathy, he received a second living related donor transplant, again with no acute rejection episodes. But, one year following the $2^{\text {nd }}$ transplant, there was evidence of BK nephropathy again with BK viremia, for which he was treated with Lefluonomide and Cidofovir. The maintenance immunosuppression for the transplant was Rapamycin. He was evaluated again five years after the $2^{\text {nd }}$ transplant for worsening renal function. Laboratory evaluation revealed lymphopenia with a total CD45 lymphocyte count of 0.77 (see Table 2 for reference values for key lymphocyte subsets), CD3 T cells $=491$ cells $/ \mathrm{uL}$, CD4 $=238$ cells $/ \mathrm{uL}, \mathrm{CD} 8=240$ cells $/ \mathrm{uL}, \mathrm{CD} 19 \mathrm{~B}$ cells $=60$ cells $/ \mathrm{uL}$ and NK cells $==208$ cells $/ \mathrm{uL}, \mathrm{CD} 4:$ $\mathrm{CD} 8$ ratio $=0.99$. There was both $\mathrm{CD} 4+\mathrm{T}$ cell and CD19+ B cell lymphopenia present. Further analysis of $B$ cell subsets revealed decreased class-switched memory B cells (CD19+CD27+IgM-IgD-) and marginal zone B cells $(\mathrm{CD} 19+\mathrm{CD} 27+\operatorname{IgM}+\mathrm{IgD}+)$. Immunoglobulin levels were normal $(\operatorname{IgG}=685, \operatorname{IgA}=228$ and $\operatorname{IgM}=48 \mathrm{mg} /$ $\mathrm{dL})$. BK viremia was significant with 11500 copies $/ \mathrm{ml}$ and $\mathrm{BK}$ viruria was at 3465000 copies $/ \mathrm{ml}$.

The early childhood history of bloody diarrhea and thrombocytopenia without recurrent infections raised the diagnostic suspicion of a mild phenotype of Wiskott-Aldrich syndrome (WAS) or the related Xlinked thrombocytopenia (XLT). Flow cytometric evaluation of intracellular WAS protein [21,22] revealed $67 \%$ positive lymphocytes for WASP (moderate intensity staining), $83 \%$ positive granulocytes and $92 \%$ positive monocytes (though staining intensity on the latter 2 populations was dim; reference range for $\%$ positive WASP populations $=95-100 \%$ ).

To confirm the flow cytometric findings and identify the specific disease variant in this patient, full-gene

\section{Table 2 Normal reference values for lymphocyte subsets} in healthy adults determined by flow cytometry

\begin{tabular}{|c|c|c|}
\hline \multirow[t]{2}{*}{ Lymphocyte subset } & \multicolumn{2}{|c|}{$95 \%$ reference values } \\
\hline & $18-55$ years & $>55$ years \\
\hline CD45 & $0.99-3.15$ thousand/uL & $1.00-3.33$ thousand/uL \\
\hline CD3 & 677-2383 cells/ $\mu \mathrm{l}$ & 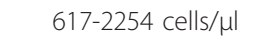 \\
\hline CD4 & 424-1509 cells/ $\mu \mathrm{l}$ & 430-1513 cells/ $\mu \mathrm{l}$ \\
\hline CD8 & 169-955 cells/ $\mu \mathrm{l}$ & $101-839$ cells/ $\mu \mathrm{l}$ \\
\hline CD19 & 99-527 cells/ $\mu \mathrm{l}$ & 31-409 cells/ $\mu$ l \\
\hline CD16+56+ & $101-678$ cells/ul & $110-657$ cells/ul \\
\hline CD3 & $59-83 \%$ & $49-87 \%$ \\
\hline CD4 & $31-59 \%$ & $32-67 \%$ \\
\hline CD8 & $12-38 \%$ & $8-40 \%$ \\
\hline CD19 & $6-22 \%$ & $3-20 \%$ \\
\hline CD16+56+ & $6-27 \%$ & $6-35 \%$ \\
\hline
\end{tabular}

Data derived from 207 healthy adult male and female donors. Pediatric reference ranges for T, B and NK cells [147]. 
sequencing (including intron-exon boundaries) of the WAS gene was performed, and revealed a splice-site mutation in intron 6 (IVS $6+5,559+5 ; \mathrm{G}>\mathrm{A}$ ), which resulted in a frameshift mutation with a premature termination of the protein at 190 amino acid residues (502 amino acids for the full-length protein). Other reports have shown that this mutation is associated with XLT, an allelic variant of WAS [23], and is in fact a "hotspot" mutation found in approximately $9 \%$ of patients with XLT [24]. The genetic pedigree of the patient (Figure 2A) did not reveal a clear or well-documented family history of WAS or XLT though there were relatives with possible features of WAS/XLT.

WAS is an X-linked disease characterized by a clinical triad of thrombocytopenia, eczema and recurrent infections, but these features may be seen in only 1 out of 4 WAS patients so the initial diagnosis can be easily overlooked. The most reliable features of WAS are thrombocytopenia (platelet count less than 70,000 in a patient without splenectomy) with low platelet volume $(<5 \mathrm{fl})[25,26]$. Approximately $1 / 3^{\text {rd }}$ of WAS patients have a life-threatening bleeding episode prior to diagnosis. Recurrent sino-pulmonary infections as well as viral infections (Varicella, HSV 1 and 2, molluscum contagiosum, and warts) are common. Eczema is seen in the majority of WAS patients $(>80 \%)$ while eosinophilia is seen in greater than $30 \%$ of patients and elevations in IgE levels are not uncommon. Autoimmune and inflammatory manifestations are quite common (approximately $40-72 \%$ of patients) and about a quarter of these

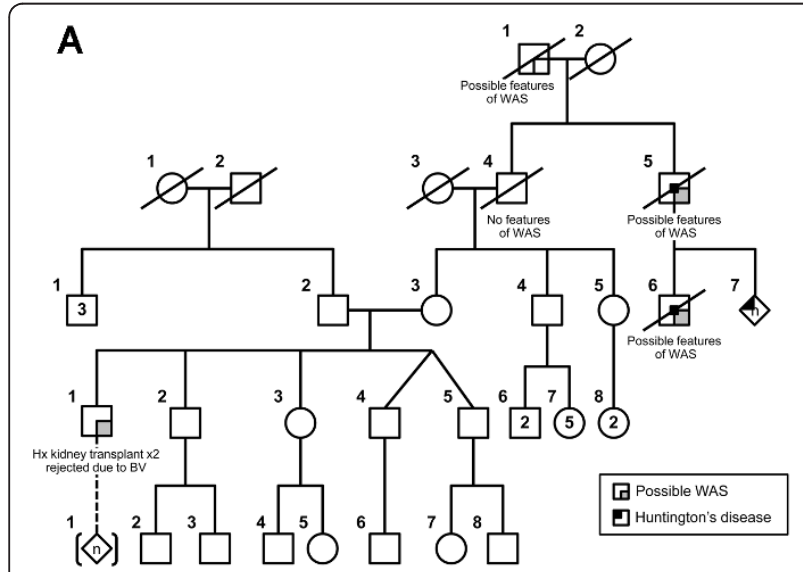

\section{B}
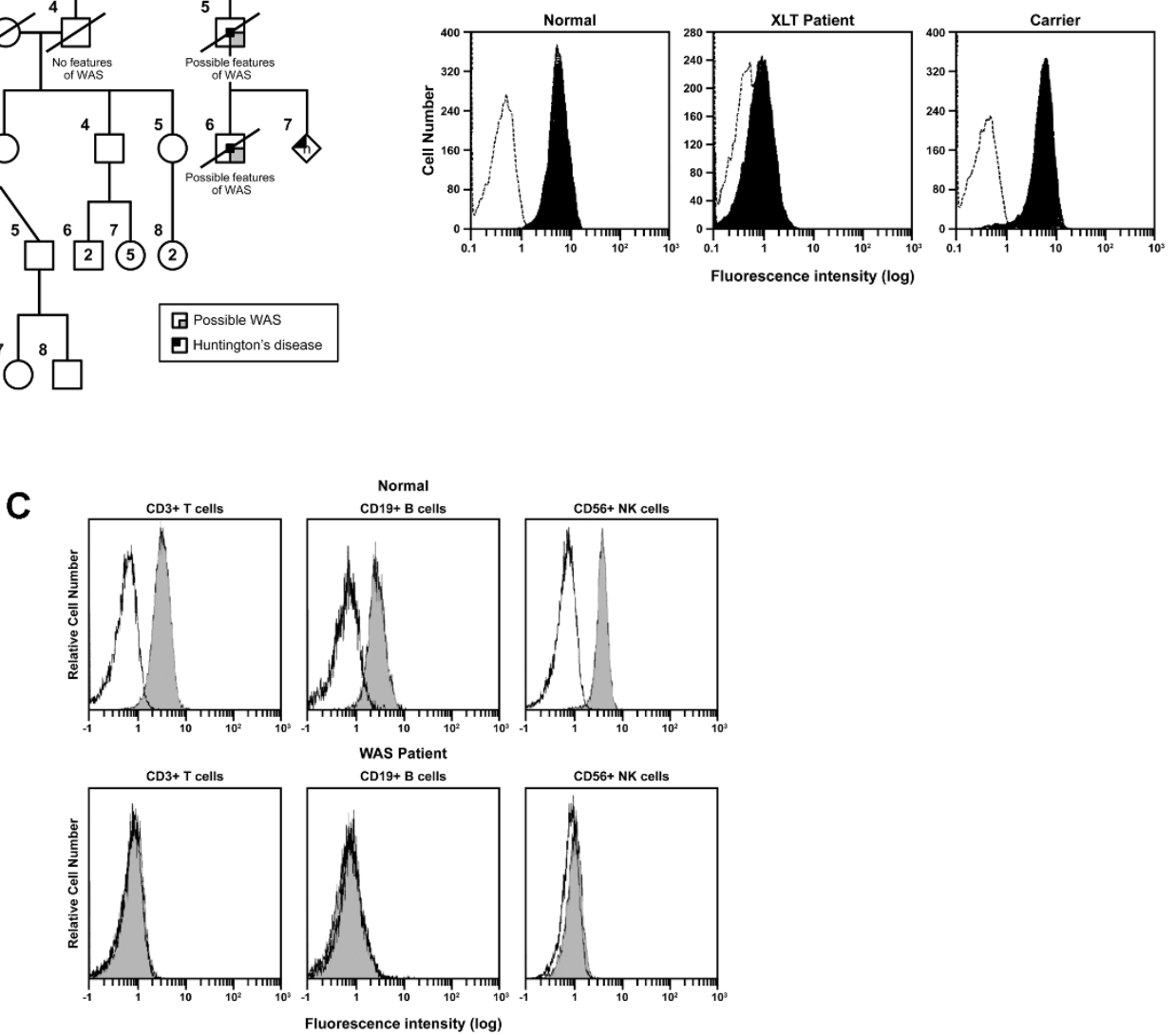

Figure 2 Evaluation for Wiskott-Aldrich syndrome (WAS) and related allelic variant, $\mathbf{X}$-linked thrombocytopenia (XLT). A) Pedigree analysis for patient (Case 2) with X-linked thrombocytopenia (XLT). B) Flow cytometric analysis for Wiskott-Aldrich syndrome protein (WASP) in lymphocytes in XLT patient and carrier. Figure reproduced with permission of American Society of Hematology, from "X-linked thrombocytopenia identified by flow cytometric demonstration of defective Wiskott-Aldrich syndrome protein in lymphocytes", Kanegane et al, 95: 1110-1111, 2000; permission conveyed through Copyright Clearance Center, Inc [38]. C) Flow cytometric analysis for Wiskott-Aldrich syndrome protein (WASP) in lymphocytes in WAS patient. Figure reprinted from Journal of Immunological Methods, 260, Kawai et al., Flow cytometric determination of intracytoplasmic Wiskott-Aldrich syndrome protein in peripheral blood lymphocyte subpopulations, p.195-205 [21], Copyright (2000), with permission from Elsevier. 
patients have multiple autoimmune features. Autoimmune hemolytic anemia (AIHA) is the most common autoimmunity seen in WAS patients $(\sim 36 \%)$ and is a poor prognostic factor.

Profound immunological anomalies are present in WAS patients and include defects in both cellular and humoral immunity. While lymphopenia can develop over time, typically IgG levels are normal with normal to low IgM, and increased IgA and IgE. There is evidence of decreased class-switched memory B cells and antibody responses to vaccine antigens, both protein and polysaccharide, are low, while responses to live viral antigens are paradoxically normal. Lymphocyte proliferative responses to mitogens, antigens and anti-CD3 stimulation are low. NK cell function and leukocyte chemotaxis are variable, and most, but not all WAS patients have low CD43 (sialophorin) expression on $\mathrm{T}$ cells [25-27].

Mutations in WAS are associated with distinct clinical phenotypes, and mutations that significantly affect WAS protein function lead to the most severe phenotype, which is further complicated by autoimmunity and malignancies [25,28]. XLT is an allelic variant of WAS [29-32] and is characterized by thrombocytopenia and small platelets. Typically, serious immunological anomalies are uncommon in XLT, though elevated IgA and IgE and mild eczema can be present. XLT patients have a higher risk of sepsis after splenectomy and slightly higher risk for neoplasia, autoimmunity and IgA nephropathy [24,33,34]. Missense mutations in exon 1 and 2 of the WAS gene are most commonly associated with XLT, in fact, $3 / 4^{\text {ths }}$ of the mutations in XLT are missense and approximately $12 \%$ are splice-site [23,31]. Other allelic disease variants due to WAS mutations include intermittent thrombocytopenia [35] and congenital X-linked neutropenia without the clinical characteristics of WAS or XLT [36,37]. Somatic reversions have been reported in several WAS patients where the disease-causing mutation has spontaneously reverted to wild-type state in subsets of hematopoietic cells resulting in somatic mosaicism [25].

While WAS and XLT in male patients and female carriers can be identified in the laboratory by flow cytometric analysis as previously mentioned (Figure 2B and $2 C)[38,39]$, the role of genetic testing cannot be understated due to the above-described allelic variants, which highlight the genotype-phenotype variability observed in this immunodeficiency.

Returning to the patient presented here, it is quite evident from the clinical history, flow cytometric evaluation of WAS protein (WASP) and WAS gene sequencing that the patient has a diagnosis of XLT. His renal disease was likely related to the underlying WAS mutation since WAS variants with increased IgA and impaired renal function have been reported [40], but his recurrent BKV infection and associated nephropathy suggest impaired immunological function, related to the XLT, which coupled with transplant immunosuppression is likely responsible for a profound immune compromise, and recurrent loss of allografts. Therefore, in patients with XLT or WAS undergoing renal transplantation, it may be worthwhile re-thinking conventional immunosuppression approaches due to the underlying immunodeficiency. Also, knowing the specific genetic diagnosis provides helpful information on additional screening for the patient due to the increased risk of malignancy [34].

It should also be kept in mind that female carriers of $\mathrm{X}$-linked diseases can be clinically symptomatic if there is skewing of lyonization and resultant inactivation of the wild-type $\mathrm{X}$-chromosome, as has been reported for XLT [41], XLA [42], and X-linked CGD [43-46].

\section{Cases 3 and 4}

A 19 year old male presented to an immunodeficiency practice with a history of peri-rectal fistulas at 7 years of age, followed by a deep left neck abscess refractory to antibiotics at 10 years of age. In general, he had a history of at least 1 skin infection per year. The causal microbe was usually methicillin-sensitive Staphylococcus aureus (MSSA) with no evidence of Aspergillus, Nocardia, Pseudomonas or Serratia species. At presentation in the recent visit he reported a peri-rectal abscess one month prior and bloody diarrhea for 1 week with sharp, diffuse abdominal pain, nausea and vomiting, fever, chills and a weight loss of 12 lbs. He was unresponsive to high-dose steroids. His laboratory data revealed both IgA and IgG antibodies to Saccharomyces cerevisiae, no evidence of Clostridium difficile and the stool culture was also negative for any pathogenic organisms but positive for leukocytes. Colonoscopy showed abnormal wall thickening of all segments of the colon and rectum. A diagnosis of severe colitis and perianal fistula was initially provided, and the rectal biopsy revealed moderate colitis with acute cryptitis and focal abscess formation. The childhood history of fistulas and abscesses with Staphylococcus raised concerns for Chronic Granulomatous Disease (CGD).

Laboratory evaluation was performed for neutrophil oxidative burst using dihydrorhodamine (DHR) flow cytometry before and after stimulation of neutrophils with Phorbol Myristate Acetate (PMA) (Figure 3A - normal, healthy donor and $3 \mathrm{~B}$ - patient). There was no evidence of DHR fluorescence after stimulation in the majority of the neutrophils (96\%) consistent with a phenotype observed in X-linked CGD (XL-CGD) (Figure 3B). However, it was interesting to note that $4 \%$ were positive for modest levels of DHR fluorescence after stimulation, which may be suggestive of somatic mosaicism due to spontaneous 


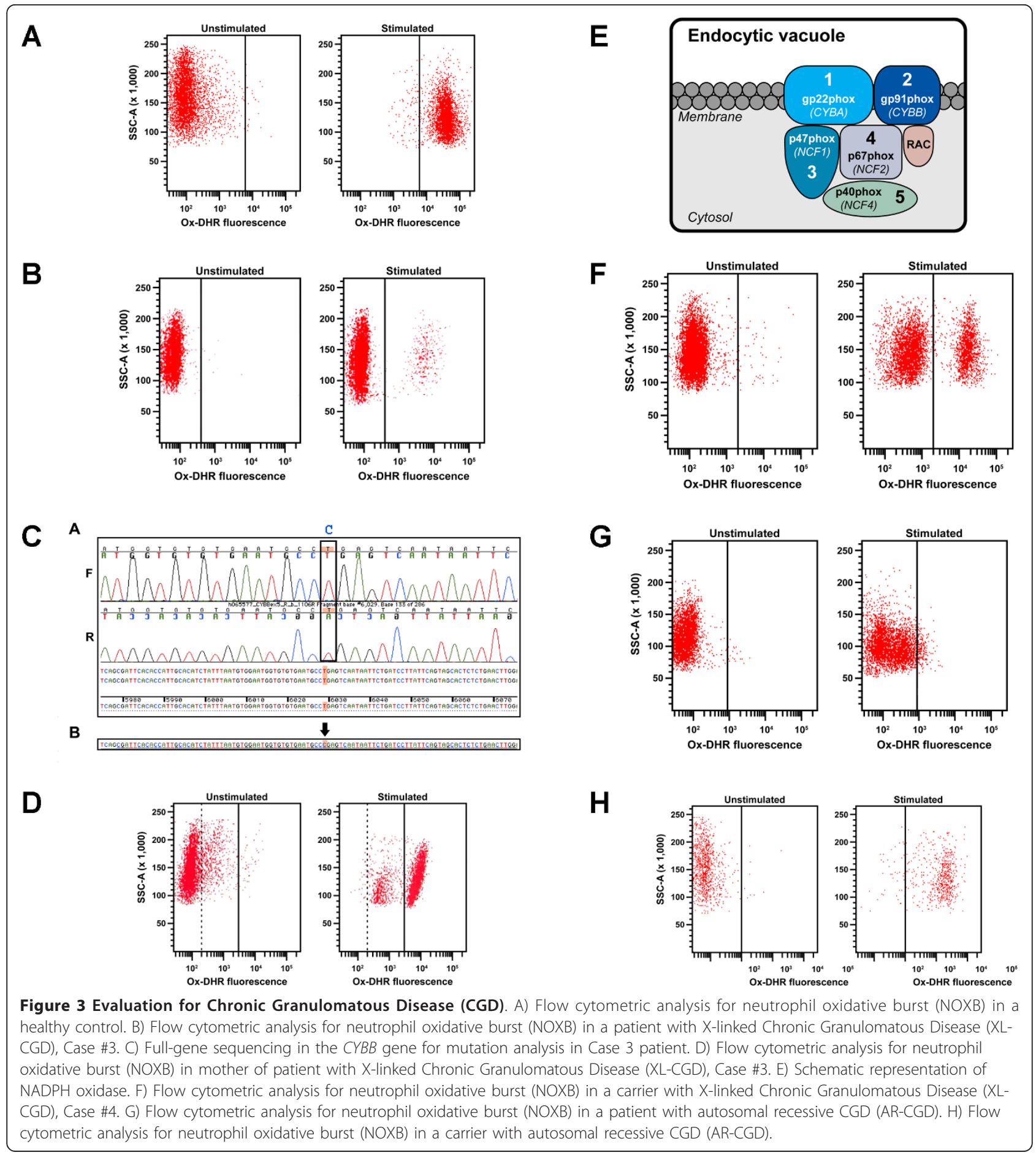

reversion in a subset of neutrophils. Genetic testing was performed with full-gene sequencing and revealed a nonsense mutation (R130X) in exon 5 of the $C Y B B$ gene, which encodes the gp91phox protein (Figure 3C). This result along with the flow cytometry data was consistent with a diagnosis of XL-CGD. Flow cytometric analysis (Figure 3D) and genetic testing (data not shown) was performed on the mother of the patient and revealed that she was not a carrier of the disease-causing mutation, and therefore, the patient had a de novo or spontaneous mutation that accounted for his clinical phenotype of CGD.

A second patient, a 23 year-old female was seen in the same immunodeficiency clinic as the above-mentioned male patient. The female patient was diagnosed with 
Crohn's disease at the age of 13 years when she had abdominal pain, fatigue and hematochezia. She underwent exploratory endoscopy and colonoscopy and her biopsy showed evidence of mild to active small bowel and colonic colitis with non-necrotizing granulomas. Her prior history was significant for skin abscesses, at least once per year, on the upper arm, gluteal region, thighs, vulvar and vaginal areas. There was no evidence of pneumonia, sinusitis, osteomyelitis, cellulitis or meningitis. She was treated almost continuously with immunosuppressive and biological therapies along with steroids since the initial diagnosis of Crohn's disease. Her family history was remarkable for XL-CGD and ocular complications of CGD. Flow cytometric testing for neutrophil oxidative burst revealed 2 populations for DHR fluorescence with a larger negative and smaller positive population (Figure 3E). Genetic testing revealed a heterozygous deletion of 16 nucleotides (c.360375del16). The patient's mother and two maternal aunts carried the same deletion mutation (one of these maternal aunts also had ulcerative colitis and primary biliary cirrhosis), and one maternal uncle died at the age of 18 months with recurrent neck abscesses. The family history also revealed two maternal great-uncles who died in childhood of unknown causes, but presumed CGD.

The clinical history of inflammatory bowel disease (IBD), recurrent skin abscesses (facial, labial, peri-rectal), poor surgical wound healing, aphthous ulcers and ocular complications all suggest a clinical phenotype of XL-CGD, due to skewing of X-chromosome inactivation (lyonization). The DHR flow cytometry results indicate that there at least 30\% neutrophils with normal oxidative burst function. Similar analyses done elsewhere showed positive DHR populations between $19-26 \%$. It has been reported that if there are greater than $10 \%$ of neutrophils with normal oxidative burst, there is typically no evidence of a clinical phenotype [47-50].

CGD is a relatively rare primary immunodeficiency with an incidence of approximately 1 in 200,000 to 250,000 individuals characterized by defects in the oxidative burst pathway that is linked with phagocytosis in myeloid cells, such as neutrophils. The primary defect in CGD is associated with the key enzyme involved in generation of the respiratory burst, NADPH oxidase. This enzyme has at least 5 subunits (Figure 3F), two of which are membrane-bound, gp91phox ( $C Y B B$ gene) and gp22phox (CYBA gene), and three are cytosolic components, p47phox (NCF1 gene), p67phox (NCF2 gene) and p40phox (NCF4 gene). The p40phox primarily interacts with p67phox and forms a larger complex with $\mathrm{p} 47 \mathrm{phox}$, which in turn interacts with a RacGTPase, $R A C 1$, permitting translocation to the membrane upon stimulation where it activates the catalytic core of the NADPH oxidase formed by the gp91phox and p22phox proteins. The most common form of CGD is X-linked accounting for approximately $70 \%$ of cases, due to mutations in the $C Y B B$ gene. The remaining $30 \%$ of cases are associated with mutations in the other subunits and inherited in an autosomal recessive (AR) manner. Mutations in NCF 1 account for $\sim 25 \%$ of the AR cases, while NCF2 and CYBA mutations are quite rare. The most recent $\mathrm{NADPH}$ subunit in which mutations were found to be associated with CGD was the p40phox (NCF4) reported in a single patient [51].

Clinically, CGD is characterized by recurrent bacterial and fungal infections of primarily the lungs, gastrointestinal tract, skin, and lymph nodes [52] caused largely by a relatively small number of pathogens - Staphylococcus aureus, Aspergillus species, Serratia marcescens, Salmonella species, Burkholderia (Pseudomonas) cepacia. Most of these pathogens are catalase-positive organisms. The most common clinical manifestations are pneumonia, cutaneous abscesses, lymphadenitis and chronic inflammatory reactions resulting in granulomas.

Carriers of XL-CGD and AR-CGD are usually asymptomatic, however, about $50 \%$ of XL-carriers have been reported to have recurrent mouth lesions, manifesting as either gingivitis or stomatitis. Further, skewing of $\mathrm{X}$-chromosome inactivation (lyonization) with inactivation of the normal X-chromosome has been reported in CGD, which could potentially confer a mild clinical phenotype in the female carrier, though this typically does not happen until the proportion of skewed, inactivated neutrophils drops below $10 \%$, as stated previously, [47-50], though healthy carriers with less than $10 \%$ normal neutrophils have also been reported [53]. The female carrier for XL-CGD presented in this article had, at all the time-points tested, greater than $10 \%$ neutrophils that were positive for oxidative burst, yet there was evidence of a clinical phenotype with recurrent skin infections and the IBD-like colitis. Further, age-related changes in X-chromosome inactivation patterns have been shown to change the relative proportion of normal to abnormal neutrophils conferring a clinical phenotype on female carriers as they age [46].

Laboratory diagnosis of CGD can be achieved by performing flow cytometric analysis to evaluate NADPH oxidase activity (oxidative burst) using dihydrorhodamine (DHR) 1,2,3 as a fluorescent marker of hydrogen peroxide generation. This is a relatively rapid and highly sensitive assay and allows the use of whole blood without purification of neutrophils, and is reasonably stable allowing measurements to be performed up to 48 hours after blood collection. Due to these reasons, this assay has replaced superoxide measurements and the Nitroblue tetrazolium (NBT) slide test as the primary screening assay for CGD [46,54-56]. 
Genetic testing is used for identification of the specific gene (encoding a subunit of NADPH oxidase) and relevant mutation. For the majority of CGD cases, gene sequencing of the $C Y B B$ gene permits identification of the causal mutation. The majority of mutations $(\sim 70 \%)$ in this gene are single nucleotide changes, which include splice-site, nonsense and missense mutations, while the remaining $\sim 30 \%$ of mutations are deletions and/or insertions [57].

DHR-based flow cytometry can also be used to identify patients with AR-CGD (Figure 3G), though this can be trickier to interpret and requires a certain level of skill as well as a more quantitative reporting format, which includes both the frequency of neutrophils positive for oxidative burst after PMA stimulation and the intensity of fluorescence per cell (MFI) $[55,58]$. Since there are 4 genetic defects (CYBA, NCF1, NCF2 and NCF4) associated with AR-CGD, one would either have to do mutation analysis for all four genes, which could be cost-prohibitive, or do additional second-tier screening tests, such as intracellular flow cytometry for the various subunits - p22phox, p47phox and p67phox [58] or immunoblot analysis prior to genetic testing. These are not widely available in clinical labs and are probably most often done in the research setting, which may, by default, necessitate genetic testing to identify the specific gene defect.

Flow cytometry can also be used for carrier detection for XL-CGD, which should typically reveal a mosaic pattern for DHR fluorescence. However, it should be kept in mind that the nature of random $\mathrm{X}$-chromosome inactivation could result in either a near-normal or a highly abnormal pattern in the flow analysis for oxidative burst in female carriers. Therefore, genetic testing remains the most robust way to perform carrier identification, especially if the familial disease-causing mutation is known. The flow-based DHR test is not sensitive enough to identify obligate carriers (parents of patients) or sibling carriers of AR-CGD caused by NCF1 or NCF 2 mutations as there appears to be normal oxidative burst on stimulation of neutrophils (Figure $3 \mathrm{H}$ ), and the assay has not been tested for CYBA carriers. Therefore, detection of AR-CGD carriers is best performed by genetic testing, though this can pose challenges with regard to the NCF1 gene, since several unrelated patients have been reported to have a dinucleotide deletion $(\triangle G T)$ in exon 2 of this gene [59-62]. A recombination event between the functional NCF1 gene and two pseudogenes, on the same chromosome, carrying this $\triangle \mathrm{GT}$ leads to the incorporation of the deletion into the NCF1 gene. This phenomenon renders carrier testing for p47phox defects difficult because normal individuals are apparently heterozygous for this GT deletion due to the pseudogenes. There are potential solutions to this problem [63,64], and while normals can be distinguished from patients and carriers, it remains unknown whether the "hybrid' protein expressing part of the sequence from the NCF1 gene with part of the sequence from the pseudogenes is really functional [65], and therefore, only NCF1-defective patients have been identified so far.

Prenatal diagnosis for CGD can be performed by fetal DNA testing along with gender analysis, if the familial mutation is known, from a chorionic villus sample (CVS) or amniotic fluid cells. The gene sequence from the fetus should be compared to the mother and a symptomatic family member as well as a normal individual to determine to confirm and validate the result. A combination of flow cytometric DHR analysis, genetic testing and family history was useful and relevant in the diagnosis of these two patients with CGD.

As the above cases exemplify, the diagnostic approach for most primary immunodeficiencies include a variety of laboratory tests and techniques, and several, but not all, of these analyses (Table 3) can be performed by multicolor and/or multiparametric flow cytometry $[2,3]$. In the case of monogenic defects, genetic testing remains the most valuable test for confirming a diagnosis, providing specific gene and mutation information as well as enabling genotype-phenotype correlations $[5,6]$. The organization and characterization of mutations for specific PID-related genes has become streamlined and widely available through the primary immunodeficiency databases [66] enabling correlation of new and previously identified mutations with clinical and immunological phenotype, besides family information.

While the above examples showcase the utility of flow cytometry to evaluate specific protein defects in the diagnosis of PIDs, it is also a very versatile tool for immunophenotyping of lymphocyte subsets and assessing lymphocyte or other leukocyte subset functions in PIDs. For example, defects in circulating B cells have been recognized in the very heterogeneous PID -Common Variable Immunodeficiency (CVID) for a number of years, and over time, several classifications involving $B$ cell subsets and immunophenotyping have evolved in an effort to organize and stratify this complex and multifaceted immunodeficiency [11,67-73]. Similarly, T cell immunophenotyping has been used to identify abnormalities or changes in naïve, memory, effector, activated, TH17 inflammatory $\mathrm{T}$ cells, regulatory $\mathrm{T}$ cells $(\mathrm{CD} 4+\mathrm{CD} 25+\mathrm{FOXP} 3+)$ and recent thymic emigrant (RTE) populations for diagnosis of several combined or cellular immunodeficiencies such as severe combined immunodeficiency (SCID), Omenn syndrome, Hyper IgE syndrome (HIES), IPEX (immunodeficiency, polyendocrinopathy, enteropathy, X-linked), CVID and DiGeorge (chromosome 22q11.2 deletion) syndrome among others [74-90]. 
Table 3 Non-disease-specific immunological tests used for the diagnosis of PIDs

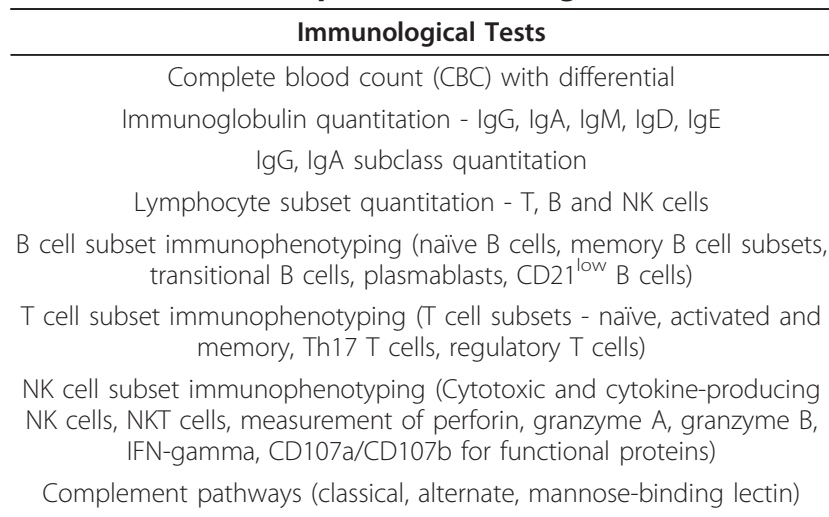

$$
\text { Cytokines }
$$

Soluble activation or inflammatory markers - e.g. soluble BAFF, soluble CD25 (IL-2R)

Antibody responses to vaccine antigens Diphtheria, tetanus, Pneumococcal, Hemophilus influenzae among others)

Lymphocyte proliferation (mitogens, antigens, anti-CD3 stimulation)

Thymopoiesis (TREC, CD4/CD8 recent thymic emigrants)

TCR receptor diversity

NK cytotoxicity (spontaneous killing, ADCC, IL-2-stimulated and PHA stimulated cytotoxicity)

CD8 T cell cytotoxicity - mitogen-stimulated, antigen-specific Costimulatory molecules

TLR signaling pathways and phosphorylated proteins

Mutation analysis for monogenic defects of immune components Measurement of innate immune responses

Chromosomal studies for chromosomal defects - deletion, translocations and rearrangements

Antigen-specific T cell quantitation

Adenosine deaminase (ADA), Purine nucleoside phosphorylase (PNP), Gluocse-6 phosphate dehydrogenase (G6PD), Myeloperoxidase (MPO)

Adhesion molecules for Leukocyte Adhesion deficiencies (CD18, CD11a, CD11b, CD15)

Neutrophil oxidative burst ${ }^{\wedge}$

Delayed type Hypersensitivity

Autoantibodies (for PID-associated autoimmunity or autoantibody-related cytopenias)

\section{Method(s)}

Automated hematology analyzer

Immunoassay methods*

Immunoassays

Flow cytometry (FC)

FC

FC

FC

Immunoassays, Hemolytic assays

In plasma or tissue culture, after T cell stimulation (multiplex methods Luminex ${ }^{\circledR}$ or flow cytometry), in cells by intracellular flow cytometry, ELISPOT

Immunoassays or multiplex flow cytometry

Serological methods, multiplex methods (e.g. Luminex ${ }^{\circledR}$ )

Thymidine (3H-t) method, FC (CFSE, Edu $\left.{ }^{\circledR}\right)$

Real-time PCR, FC

Spectratyping -molecular, FC

Radioactive method, FC

Radioactive method, FC

FC

FC, specific cytokines after TLR stimulation, Immunoblot analysis

DNA-based gene sequencing

FC

Fluorescence in-situ hybridization (FISH), array comparative genomic hybridization $(\mathrm{aCGH})$

Tetramers/Pentamers/Dextramers ${ }^{\circledR}$ by FC

Enzyme assays

FC

DHR test by FC (Nitroblue tetrazolium -NBT- test can also be used) In vivo skin test

Direct antiglobulin test (DAT or Coombs' test) for autoimmune hemolytic anemia, Immunoassays

*For a detailed list of immunoassay methods (see Table 3, page 11, Chapter 3 - Protein Analysis for Diagnostic Applications, by AT Remaley and GL Hortin, In Molecular Clinical Laboratory Immunology, Eds, Detrick, Hamilton and Folds, $7^{\text {th }}$ Ed), ${ }^{\wedge}$ Neutrophil chemotaxis and phagocytic cells have limited clinical utility, DHR - Dihydrorhodamine 1,2,3; a bone marrow biopsy can be performed for further evaluation of certain PIDs, e.g. abnormal retention of neutrophils in the marrow (myelokathexis in WHIM syndrome), aberrant production of hematopoietic precursors (Reticular dysgenesis and congenital neutropenias).

Heterogeneity in lymphocyte subsets is not restricted to only $\mathrm{T}$ and B cells, but also present in the NK cell compartment, and multicolor flow cytometry can be used to immunophenotype human NK cells in various PIDs where NK cell defects are either primary or secondary [91-95]. However, when performing immunophenotyping for circulating lymphocyte subsets, it must be kept in mind that to obtain analytically stringent data, various factors, such as diurnal changes, acute exercise, hormonal alterations, age and gender influence these populations, quantitatively and qualitatively (especially relevant for serial monitoring), and this must be taken into consideration [96-100].

Diagnosis of PIDs with $\mathrm{T}$ cell defects also often involves the use of molecular techniques, besides flow cytometry, and these include analysis of thymic function and $\mathrm{T}$ cell receptor repertoire diversity [101]. Quantitation of $\mathrm{T}$ cell receptor excision circles (TREC), which are episomal by-products of $\mathrm{T}$ cell receptor rearrangement, by polymerase chain reaction (PCR) methods, 
especially real-time PCR, has been used to determine thymic output [102-104]. However, it should be kept in mind that TREC levels are affected by cellular division as well as the longevity of naïve $T$ cells in the periphery [102] and therefore, may not be always useful as a marker for recentthymic emigration. But, use of TREC in conjunction with quantitative analysis of naïve $\mathrm{T}$ cells and/or recent thymic emigrants (RTE) by flow cytometry $[83,86]$ is likely to provide a comprehensive assessment of thymic function. Accurate interpretation of TREC and RTE data requires correlation with total T cell counts along with the use of age-appropriate reference values derived from healthy donors, both pediatric and adults (Hoeltzle et al, manuscript in preparation). $\mathrm{T}$ cell receptor (TCR) repertoire diversity can be assessed by flow cytometry, however since the panel of reagents available covers only $2 / 3^{\text {rd }}$ of the known TCR -beta gene -variable region (TCR V $\beta$ ) families, molecular techniques, such as immunoscope analysis (spectratyping), have been found to be more sensitive and stringent [105-109].

Besides identifying quantitative anomalies in various immune cell populations by flow cytometry, functional assessment of these cell populations is equally important and can be achieved, for the most part, by the same methodology, though other methods can also be used. For example, measurement of lymphocyte proliferation to mitogens, such as Phytohemagglutinin (PHA), Pokeweed mitogen (PWM) and Concanavalin A (Con A), and antigens, such as Candida albicans (CA) and Tetanus toxoid (TT) to ascertain $\mathrm{T}$ cell immune competence in PIDs [110] has long been performed by DNA incorporation of radiolabeled thymidine $\left({ }^{3} \mathrm{H}-\mathrm{T}\right)$ after stimulation of peripheral blood mononuclear cells (PBMCs) with the appropriate agent. Elimination of techniques involving radioactivity is always beneficial to the clinical laboratory, and flow cytometry-based methods, primarily using the intracellular fluorescent dye, CFSE (carboxyfluorescein diacetate succinimidyl ester), are now available for measuring cellular proliferation [111-113]. However, a recent study seems to suggest that the use of CFSE to measure lymphocyte proliferation for the diagnosis of cellular PIDs would be inaccurate due to the high rate of false positive results [114]. CFSE is also difficult to use in a high-throughput clinical laboratory due its light-sensitive nature and the requirement for pre-labeling of cells.

A more attractive alternative has been the direct incorporation into DNA of a non-radioactive compound, an alkyne-modified nucleoside (EdU, 5-ethynyl-2'deoxyuridine), which is fluorescently tagged through covalent interaction with a dye-labeled azide, and used to visualize cell proliferation by flow cytometry $[115,116]$; Erickson et al, manuscript in preparation). The flow cytometry method of measuring proliferation offers several distinct advantages over the radioactive method, besides the obvious elimination of radioactivity, including, the ability to measure cellular proliferation in distinct lymphocyte subsets, and assess cellular viability, apoptosis and death using appropriate markers, such as Annexin V and 7-AAD, in the same assay. Flow cytometry also allows measurement of other cellular functions, such as phosphorylation of proteins involved in cell signaling pathways $[117,118]$, though these assays are typically available at present only in larger clinical reference or research laboratories. An example of protein phosphorylation key to immune regulation includes the JAK-STAT pathway $[119,120]$, and mutations in at least three STAT family members (STAT1, STAT3, STAT5B) are known to be associated with distinct PIDs [121-126].

Laboratory evaluation is essential not only for the diagnosis of PIDs, but also for the evaluation and measurement of recovery of immune function after therapeutic intervention, especially, but not exclusively, in hematopoietic stem cell transplantation (HSCT) [127-133]. However, timely treatment requires early diagnosis, especially of PIDs that are fatal, if left untreated, such as SCID or severe T cell lymphopenia [134-136]. The adoption of newborn screening (NBS) for SCID and other $\mathrm{T}$ cell deficiencies as part of the NBS panel, by the federal advisory committee on heritable disorders in newborns and children, in 2010 has ushered in a new era of population-based screening for these critical PIDs. The screening protocol involves detection of TREC in dried blood spots, followed by additional confirmatory flow cytometry and genetic testing when appropriate [137-144]. Early identification of SCID and T cell-deficient patients through the NBS program will pave the way for these infants to receive rapid intervention resulting in improved overall survival.

In conclusion, laboratory-based testing for PIDs is a rapidly expanding, constantly evolving field that plays an integral role in the diagnostic work-up of these complex immunodeficiencies, but also simultaneously provides valuable insights into human immunobiology. However, quality control and standardization of techniques, methods, platforms and reference values is essential to successful and accurate outcomes for immunological analyses within the laboratory, and clinical trial models may provide a frame of reference for such endeavors $[145,146]$.

\section{Appendix \\ Detailed Figure Legends:}

Figure 1A. Flow cytometric evaluation for Btk protein in a healthy control. Btk protein analysis is performed by intracellular flow cytometry in B cells and monocytes from a normal donor. The B cells (marked 
in blue) and the monocytes (olive) express normal levels of Btk protein intracellularly as would be expected (lower plot, right of solid line). The isotype control is shown in the top panel (left of solid line).

1B. Flow cytometric evaluation for Btk protein in Case 1 patient. Btk protein analysis is performed by intracellular flow cytometry in monocytes (since B cells were absent) from the patient. The monocytes (olive) express normal levels of Btk protein intracellularly (lower plot). However, the presence of protein does not eliminate the possibility of functional defects. The isotype control is shown in the top panel (left of solid line).

1C. Full-gene sequencing in the BTK gene for mutation analysis in Case 1 patient. Full-gene sequencing in the forward (F) and reverse (R) direction (all exons, intron-exon boundaries and 5' and 3' untranslated regions were covered) of the $B T K$ gene in patient (A) and wild-type normal control (B) revealed the presence of a hemizygous nonsense mutation in exon 15 (old nomenclature, exon 14 -new nomenclature, g.68137 G>A; c.1895 G>A, TGG>TAG; p.W588X) resulting in premature truncation of the translated protein. Since the defect was present in the latter part of the C-terminal portion of the protein it allowed for normal protein expression within monocytes but abrogated function. Six other XLA patients, besides this patient, have been described as having this specific mutation in the $B T K$ gene.

1D. Schematic representation of Btk protein structural organization. The Btk protein has several distinct domains and is a member of the Tec-family of kinases, which are non-receptor tyrosine kinases. The five domains of Btk include a pleckstrin-homology domain $(\mathrm{PH})$, a Tec-homology domain (TH) and 3 Src-homology domains $(\mathrm{SH})$. The nonsense mutation present in the patient was in the SH1 kinase (key functional region) domain resulting in a loss of 72 amino acids in the C-terminal portion of the protein.

1E. Schematic representation of Btk in B cell development. Btk plays a key role in B cell development in the bone marrow and partially contributes to the transition of pro- $B$ cells to pre- $B$ cells (dotted line) from the pro-B cell to pre- $B$ cell stage, but is really crucial for differentiation of pre-B cells into immature B cells (represented by solid line). Absence of Btk protein leads to an arrest in B cell development and significant B cell lymphopenia in the periphery. Btk expression in the normal $\mathrm{B}$ cell lineage is downregulated in plasma cells.

Figure 2A. Pedigree analysis for patient (Case 2) with X-linked thrombocytopenia (XLT). XLT is an allelic variant of Wiskott-Aldrich syndrome (WAS) and is due to mutations in the WAS gene.

2B. Flow cytometric analysis for Wiskott-Aldrich syndrome protein (WASP) in lymphocytes in XLT patient and carrier. Data shown in this figure is obtained from Kanegane et al (ref number 38). Intracellular flow cytometry was performed in lymphocytes from an XLT patient, carrier mother and healthy control. The patient shows partial expression of WASP consistent with the milder clinical and immunological phenotype observed in XLT patients. The carrier mother resembles the control with normal expression of WASP in lymphocytes.

2C. Flow cytometric analysis for Wiskott-Aldrich syndrome protein (WASP) in lymphocytes in WAS patient. Data shown in this figure is obtained from Kawai et al (ref number 21). Intracellular flow cytometry was performed in T, B and NK cells from a healthy control (top panel) and a WAS patient (lower panel). The patient depicted here shows no expression of WASP. Absence of protein correlates with a severe phenotype in WAS patients.

Figure 3A. Flow cytometric analysis for neutrophil oxidative burst (NOXB) in a healthy control. Neutrophils from a healthy donor are evaluated for NADPH oxidase activity before (unstimulated) or after stimulation with Phorbol Myristate Acetate (PMA). The principle of this assay is that a non-fluorescent compound, Dihydrorhodamine 1,2, 3 when phagocytosed by normal, activated neutrophils (post-PMA stimulation) is oxidized by hydrogen peroxide produced during normal activated neutrophil respiratory burst, to Rhodamine $1,2,3$, a green fluorescent compound, which can be detected by flow cytometry. Therefore, the fluorescence detected is an indirect measure of neutrophil oxidative burst function (Oxidized DHR1,2,3). The healthy control demonstrates normal neutrophil oxidative burst after stimulation.

3B. Flow cytometric analysis for neutrophil oxidative burst (NOXB) in a patient with X-linked Chronic Granulomatous Disease (XL-CGD), Case \#3. Absence of normal oxidative burst in the majority of neutrophils (96\%) is observed in the patient sample after stimulation, similar to that seen in the unstimulated sample. There is a very small population (4\%) of neutrophils which show oxidative burst after stimulation. This result is consistent with a diagnosis of XL-CGD.

3C. Full-gene sequencing in the $C Y B B$ gene for mutation analysis in Case 3 patient. Full-gene sequencing of the $C Y B B$ gene, encoding the gp91phox protein, in the patient (A), was performed in the forward (F) and reverse $(R)$ direction (all exons, intron-exon boundaries were covered) and revealed the presence of a hemizygous nonsense mutation in exon 5, p.R130X (reference wild-type $C Y B B$ sequence provided in panel B). This was established as a de novo mutation in the patient since the mother was not a carrier for this specific mutation. 
3D. Flow cytometric analysis for neutrophil oxidative burst $(\mathrm{NOXB})$ in mother of patient with $\mathrm{X}$ linked Chronic Granulomatous Disease (XL-CGD), Case \#3. Normal oxidative burst in the majority of neutrophils is observed in the mother's sample after stimulation (see right of dotted and solid lines, not accounting for the modest background in the unstimulated sample), similar to that seen in a healthy control. The limited background activation observed in the unstimulated sample can be seen in samples due to time lapse from blood collection and transportation conditions (right of solid line marks oxidative burst accounting for the background). This result is therefore not consistent with carrier status for XL-CGD, which was verified by gene sequencing (data not shown).

3E. Schematic representation of NADPH oxidase. NADPH oxidase, a key enzyme in the respiratory burst pathway consists of 5 subunits, 2 of which are membrane-bound - gp91phox and p22phox. The remaining 3 cytosolic subunits include the p47phox, p67phox and p40phox. These interact with Rac1, a RacGTPase molecule. Mutations in $C Y B B$ resulting in defective gp91phox account for the majority of cases of Chronic Granulomatous Disease (CGD).

3F. Flow cytometric analysis for neutrophil oxidative burst (NOXB) in a carrier with $\mathrm{X}$-linked Chronic Granulomatous Disease (XL-CGD), Case \#4. Two populations are observed for neutrophil oxidative burst after stimulation - a larger negative and a smaller positive population, consistent with carrier status for XL-CGD, which was confirmed by gene sequencing (heterozygous 16 bp deletion in the $C Y B B$ gene, c.360-375del16) and family history. The patient was clinically symptomatic for CGD consistent with the skewing of lyonization (X-chromosome inactivation) observed in the flow cytometry assay for neutrophil oxidative burst.

3G. Flow cytometric analysis for neutrophil oxidative burst (NOXB) in a patient with autosomal recessive CGD (AR-CGD). Neutrophils from a female patient shows impaired oxidative burst after stimulation in a pattern consistent with AR-CGD. Flow analysis was confirmed by gene sequencing which revealed a mutation in the NCF1 gene encoding p47phox, which accounts for the majority of AR-CGD cases.

$3 \mathrm{H}$. Flow cytometric analysis for neutrophil oxidative burst (NOXB) in a carrier with autosomal recessive CGD (AR-CGD). Normal neutrophil oxidative burst observed after stimulation in female patient, similar to healthy control. Family history revealed a female sibling diagnosed with AR-CGD with a pathogenic mutation identified in the NCF1 (p47phox) gene. However, the flow cytometry assay cannot be effectively used to identify carriers for AR-CGD.

\section{Acknowledgements}

The author acknowledges the physicians and patients associated with the case studies presented in this review.

\section{Competing interests}

The author declares that they have no competing interests.

Received: 4 January 2011 Accepted: 9 April 2011 Published: 9 April 2011

\section{References}

1. Oliveira JB, Fleisher TA: Laboratory evaluation of primary immunodeficiencies. J Allergy Clin Immunol 2010, 125:S297-305.

2. Fleisher TA, Oliveira JB: Functional flow cytometry testing: an emerging approach for the evaluation of genetic disease. Clin Chem 2009, 55:389-390.

3. O'Gorman MR: Role of flow cytometry in the diagnosis and monitoring of primary immunodeficiency disease. Clin Lab Med 2007, 27:591-626, vii.

4. Oliveira JB, Notarangelo LD, Fleisher TA: Applications of flow cytometry for the study of primary immune deficiencies. Curr Opin Allergy Clin Immunol 2008, 8:499-509

5. Hsu AP, Fleisher TA, Niemela JE: Mutation analysis in primary immunodeficiency diseases: case studies. Curr Opin Allergy Clin Immunol 2009, 9:517-524.

6. Notarangelo $L D$, Sorensen $R$ : Is it necessary to identify molecular defects in primary immunodeficiency disease? J Allergy Clin Immunol 2008, 122:1069-1073.

7. Hudson KL, Holohan MK, Collins FS: Keeping pace with the times-the Genetic Information Nondiscrimination Act of 2008. N Engl J Med 2008, 358:2661-2663.

8. Notarangelo LD, Fischer A, Geha RS, Casanova JL, Chapel H, Conley ME, Cunningham-Rundles C, Etzioni A, Hammartrom L, Nonoyama S, et al: Primary immunodeficiencies: 2009 update. J Allergy Clin Immunol 2009, 124:1161-1178

9. Samarghitean C, Vihinen M: Bioinformatics services related to diagnosis of primary immunodeficiencies. Curr Opin Allergy Clin Immunol 2009, 9:531-536

10. Conley ME, Dobbs AK, Farmer DM, Kilic S, Paris K, Grigoriadou S, CoustanSmith E, Howard V, Campana D: Primary B cell immunodeficiencies: comparisons and contrasts. Annu Rev Immunol 2009, 27:199-227.

11. Warnatz K, Denz A, Drager R, Braun M, Groth C, Wolff-Vorbeck G, Eibel H, Schlesier M, Peter HH: Severe deficiency of switched memory B cells $(\mathrm{CD} 27(+) \lg M(-) \lg \mathrm{D}(-))$ in subgroups of patients with common variable immunodeficiency: a new approach to classify a heterogeneous disease. Blood 2002, 99:1544-1551.

12. Sochorova K, Horvath R, Rozkova D, Litzman J, Bartunkova J, Sediva A, Spisek R: Impaired Toll-like receptor 8-mediated IL-6 and TNF-alpha production in antigen-presenting cells from patients with X-linked agammaglobulinemia. Blood 2007, 109:2553-2556.

13. Taneichi H, Kanegane H, Sira MM, Futatani T, Agematsu K, Sako M, Kaneko H, Kondo N, Kaisho T, Miyawaki T: Toll-like receptor signaling is impaired in dendritic cells from patients with X-linked agammaglobulinemia. Clin Immunol 2008, 126:148-154.

14. Marron TU, Rohr K, Martinez-Gallo M, Yu J, Cunningham-Rundles C: TLR signaling and effector functions are intact in XLA neutrophils. Clin Immunol 2010, 137:74-80

15. Gaspar HB, Ferrando M, Caragol I, Hernandez M, Bertran JM, De Gracia X, Lester T, Kinnon C, Ashton E, Espanol T: Kinase mutant Btk results in atypical X-linked agammaglobulinaemia phenotype. Clin Exp Immunol 2000, 120:346-350

16. Winkelstein JA, Marino MC, Lederman HM, Jones SM, Sullivan K, Burks AW Conley ME, Cunningham-Rundles C, Ochs HD: X-linked agammaglobulinemia: report on a United States registry of 201 patients. Medicine (Baltimore) 2006, 85:193-202.

17. Futatani T, Miyawaki T, Tsukada S, Hashimoto S, Kunikata T, Arai S, Kurimoto M, Niida Y, Matsuoka H, Sakiyama Y, et al: Deficient expression of Bruton's tyrosine kinase in monocytes from $X$-linked agammaglobulinemia as evaluated by a flow cytometric analysis and its clinical application to carrier detection. Blood 1998, 91:595-602.

18. Nonoyama S, Tsukada S, Yamadori T, Miyawaki T, Jin YZ, Watanabe C, Morio T, Yata J, Ochs HD: Functional analysis of peripheral blood B cells 
in patients with X-linked agammaglobulinemia. J Immunol 1998, 161:3925-3929.

19. Broides A, Yang W, Conley ME: Genotype/phenotype correlations in Xlinked agammaglobulinemia. Clin Immunol 2006, 118:195-200.

20. Graziani S, Di Matteo G, Benini L, Di Cesare S, Chiriaco M, Chini L, Chianca $M$, De lorio F, La Rocca M, lannini R, et al: Identification of a Btk mutation in a dysgammaglobulinemic patient with reduced $B$ cells: XLA diagnosis or not? Clin Immunol 2008, 128:322-328.

21. Kawai S, Minegishi M, Ohashi Y, Sasahara Y, Kumaki S, Konno T, Miki H, Derry J, Nonoyama S, Miyawaki T, et al: Flow cytometric determination of intracytoplasmic Wiskott-Aldrich syndrome protein in peripheral blood lymphocyte subpopulations. J Immunol Methods 2002, 260:195-205.

22. Nakajima M, Yamada M, Yamaguchi K, Sakiyama Y, Oda A, Nelson DL, Yawaka Y, Ariga T: Possible application of flow cytometry for evaluation of the structure and functional status of WASP in peripheral blood mononuclear cells. Eur J Haematol 2009, 82:223-230.

23. Jin Y, Mazza C, Christie JR, Giliani S, Fiorini M, Mella P, Gandellini F, Stewart DM, Zhu Q, Nelson DL, et al: Mutations of the Wiskott-Aldrich Syndrome Protein (WASP): hotspots, effect on transcription, and translation and phenotype/genotype correlation. Blood 2004, 104:4010-4019.

24. Albert MH, Bittner TC, Nonoyama S, Notarangelo LD, Burns S, Imai K, Espanol T, Fasth A, Pellier I, Strauss G, et al: X-linked thrombocytopenia (XLT) due to WAS mutations: clinical characteristics, long-term outcome, and treatment options. Blood 2010, 115:3231-3238.

25. Notarangelo LD, Miao CH, Ochs HD: Wiskott-Aldrich syndrome. Curr Opin Hematol 2008, 15:30-36.

26. Orange JS, Stone KD, Turvey SE, Krzewski K: The Wiskott-Aldrich syndrome. Cell Mol Life Sci 2004, 61:2361-2385.

27. Thrasher AJ, Burns SO: WASP: a key immunological multitasker. Nat Rev Immunol 2010, 10:182-192.

28. Imai K, Morio T, Zhu Y, Jin Y, Itoh S, Kajiwara M, Yata J, Mizutani S, Ochs HD Nonoyama S: Clinical course of patients with WASP gene mutations. Blood 2004, 103:456-464.

29. Donner M, Schwartz M, Carlsson KU, Holmberg L: Hereditary X-linked thrombocytopenia maps to the same chromosomal region as the Wiskott-Aldrich syndrome. Blood 1988, 72:1849-1853.

30. Notarangelo LD, Notarangelo LD, Ochs HD: WASP and the phenotypic range associated with deficiency. Curr Opin Allergy Clin Immunol 2005, 5:485-490.

31. Villa A, Notarangelo L, Macchi P, Mantuano E, Cavagni G, Brugnoni D, Strina D, Patrosso MC, Ramenghi U, Sacco MG, et al: X-linked thrombocytopenia and Wiskott-Aldrich syndrome are allelic diseases with mutations in the WASP gene. Nat Genet 1995, 9:414-417.

32. Zhu Q, Watanabe C, Liu T, Hollenbaugh D, Blaese RM, Kanner SB, Aruffo A, Ochs HD: Wiskott-Aldrich syndrome/X-linked thrombocytopenia: WASP gene mutations, protein expression, and phenotype. Blood 1997, 90:2680-2689.

33. Matsukura H, Kanegane H, Miya K, Ohtsubo K, Higuchi A, Tanizawa T, Miyawaki T: IgA nephropathy associated with X-linked thrombocytopenia. Am J Kidney Dis 2004, 43:e7-12.

34. Shcherbina A, Candotti F, Rosen FS, Remold-O'Donnell E: High incidence of lymphomas in a subgroup of Wiskott-Aldrich syndrome patients. $\mathrm{Br} \mathrm{J}$ Haematol 2003, 121:529-530.

35. Notarangelo LD, Mazza C, Giliani S, D’Aria C, Gandellini F, Ravelli C, Locatelli MG, Nelson DL, Ochs HD, Notarangelo LD: Missense mutations of the WASP gene cause intermittent X-linked thrombocytopenia. Blood 2002, 99:2268-2269.

36. Ancliff PJ, Blundell MP, Cory GO, Calle Y, Worth A, Kempski H, Burns S, Jones GE, Sinclair J, Kinnon C, et al: Two novel activating mutations in the Wiskott-Aldrich syndrome protein result in congenital neutropenia. Blood 2006, 108:2182-2189.

37. Devriendt K, Kim AS, Mathijs G, Frints SG, Schwartz M, Van Den Oord JJ, Verhoef GE, Boogaerts MA, Fryns JP, You D, et al: Constitutively activating mutation in WASP causes X-linked severe congenital neutropenia. Nat Genet 2001, 27:313-317.

38. Kanegane H, Nomura K, Miyawaki T, Sasahara Y, Kawai S, Tsuchiya S, Murakami G, Futatani T, Ochs HD: X-linked thrombocytopenia identified by flow cytometric demonstration of defective Wiskott-Aldrich syndrome protein in lymphocytes. Blood 2000, 95:1110-1111.
39. Yamada M, Ariga T, Kawamura N, Yamaguchi K, Ohtsu M, Nelson DL, Kondoh T, Kobayashi I, Okano M, Kobayashi K, Sakiyama Y: Determination of carrier status for the Wiskott-Aldrich syndrome by flow cytometric analysis of Wiskott-Aldrich syndrome protein expression in peripheral blood mononuclear cells. J Immunol 2000, 165:1119-1122.

40. Webb MC, Andrews PA, Koffman CG, Cameron JS: Renal transplantation in Wiskott-Aldrich syndrome. Transplantation 1993, 56:1585.

41. Inoue H, Kurosawa H, Nonoyama S, Imai K, Kumazaki H, Matsunaga T, Sato Y, Sugita K, Eguchi M: X-linked thrombocytopenia in a girl. $\mathrm{Br} J$ Haematol 2002, 118:1163-1165.

42. Takada H, Kanegane H, Nomura A, Yamamoto K, Ihara K, Takahashi Y, Tsukada S, Miyawaki T, Hara T: Female agammaglobulinemia due to the Bruton tyrosine kinase deficiency caused by extremely skewed Xchromosome inactivation. Blood 2004, 103:185-187.

43. Lewis EM, Singla M, Sergeant S, Koty PP, McPhail LC: X-linked chronic granulomatous disease secondary to skewed $\times$ chromosome inactivation in a female with a novel CYBB mutation and late presentation. Clin Immunol 2008, 129:372-380.

44. Lun A, Roesler J, Renz H: Unusual late onset of X-linked chronic granulomatous disease in an adult woman after unsuspicious childhood. Clin Chem 2002, 48:780-781.

45. Roesler J: Carriers of $\mathrm{X}$-linked chronic granulomatous disease at risk. Clin Immunol 2009, 130:233, author reply 234.

46. Rosen-Wolff A, Soldan W, Heyne K, Bickhardt J, Gahr M, Roesler J: Increased susceptibility of a carrier of X-linked chronic granulomatous disease (CGD) to Aspergillus fumigatus infection associated with age-related skewing of lyonization. Ann Hematol 2001, 80:113-115.

47. Bolscher BG, de Boer M, de Klein A, Weening RS, Roos D: Point mutations in the beta-subunit of cytochrome b558 leading to X-linked chronic granulomatous disease. Blood 1991, 77:2482-2487.

48. Curnutte JT, Hopkins PJ, Kuhl W, Beutler E: Studying $\times$ inactivation. Lancet 1992, 339:749.

49. Mills EL, Rholl KS, Quie PG: X-linked inheritance in females with chronic granulomatous disease. J Clin Invest 1980, 66:332-340.

50. Winkelstein JA, Marino MC, Johnston RB, Boyle J, Curnutte J, Gallin Jl, Malech HL, Holland SM, Ochs H, Quie P, et al: Chronic granulomatous disease. Report on a national registry of 368 patients. Medicine (Baltimore) 2000, 79:155-169.

51. Matute JD, Arias AA, Wright NA, Wrobel I, Waterhouse CC, Li XJ, Marchal CC, Stull ND, Lewis DB, Steele M, et al: A new genetic subgroup of chronic granulomatous disease with autosomal recessive mutations in p40 phox and selective defects in neutrophil NADPH oxidase activity. Blood 2009, 114:3309-3315.

52. Rosenzweig SD, Holland SM: Phagocyte immunodeficiencies and their infections. J Allergy Clin Immunol 2004, 113:620-626.

53. Roos D, Weening RS, de Boer M, Meerhof LJ: Heterogeneity in chronic granulomatous disease. In Progress in Immunodeficiency Research and Therapy.. 2 edition. Edited by: Vossen J, Griscelli C. Amsterdam: Elsevier; 1986:139-146.

54. O'Gorman MR, Corrochano V: Rapid whole-blood flow cytometry assay for diagnosis of chronic granulomatous disease. Clin Diagn Lab Immunol 1995, 2:227-232.

55. Vowells SJ, Fleisher TA, Sekhsaria S, Alling DW, Maguire TE, Malech HL: Genotype-dependent variability in flow cytometric evaluation of reduced nicotinamide adenine dinucleotide phosphate oxidase function in patients with chronic granulomatous disease. J Pediatr 1996, 128:104-107.

56. Vowells SJ, Sekhsaria S, Malech HL, Shalit M, Fleisher TA: Flow cytometric analysis of the granulocyte respiratory burst: a comparison study of fluorescent probes. J Immunol Methods 1995, 178:89-97.

57. Vihinen M, Arredondo-Vega FX, Casanova JL, Etzioni A, Giliani S, Hammarstrom L, Hershfield MS, Heyworth PG, Hsu AP, Lahdesmaki A, et al: Primary immunodeficiency mutation databases. Adv Genet 2001, 43:103-188.

58. Yu G, Hong DK, Dionis KY, Rae J, Heyworth PG, Curnutte JT, Lewis DB: Focus on FOCIS: the continuing diagnostic challenge of autosomal recessive chronic granulomatous disease. Clin Immunol 2008, 128:117-126.

59. Casimir CM, Bu-Ghanim HN, Rodaway AR, Bentley DL, Rowe P, Segal AW: Autosomal recessive chronic granulomatous disease caused by deletion at a dinucleotide repeat. Proc Natl Acad Sci USA 1991, 88:2753-2757. 
60. Roesler J, Curnutte JT, Rae J, Barrett D, Patino P, Chanock SJ, Goerlach A: Recombination events between the p47-phox gene and its highly homologous pseudogenes are the main cause of autosomal recessive chronic granulomatous disease. Blood 2000, 95:2150-2156.

61. Roos D, de Boer M, Kuribayashi F, Meischl C, Weening RS, Segal AW, Ahlin A, Nemet K, Hossle JP, Bernatowska-Matuszkiewicz E, MiddletonPrice $\mathrm{H}$ : Mutations in the $\mathrm{X}$-linked and autosomal recessive forms of chronic granulomatous disease. Blood 1996, 87:1663-1681.

62. Vazquez N, Lehrnbecher T, Chen R, Christensen BL, Gallin Jl, Malech $\mathrm{H}_{\text {, }}$ Holland S, Zhu S, Chanock SJ: Mutational analysis of patients with p47phox-deficient chronic granulomatous disease: The significance of recombination events between the p47-phox gene (NCF1) and its highly homologous pseudogenes. Exp Hematol 2001, 29:234-243.

63. Dekker J, de Boer M, Roos D: Gene-scan method for the recognition of carriers and patients with p47(phox)-deficient autosomal recessive chronic granulomatous disease. Exp Hematol 2001, 29:1319-1325.

64. Noack D, Rae J, Cross AR, Ellis BA, Newburger PE, Curnutte JT, Heyworth PG: Autosomal recessive chronic granulomatous disease caused by defects in NCF-1, the gene encoding the phagocyte p47-phox: mutations not arising in the NCF-1 pseudogenes. Blood 2001, 97:305-311.

65. Heyworth PG, Noack D, Cross AR: Identification of a novel NCF-1 (p47phox) pseudogene not containing the signature GT deletion: significance for A47 degrees chronic granulomatous disease carrier detection. Blood 2002, 100:1845-1851.

66. Piirila $\mathrm{H}$, Valiaho J, Vihinen M: Immunodeficiency mutation databases (IDbases). Hum Mutat 2006, 27:1200-1208.

67. Aghamohammadi A, Parvaneh N, Rezaei N: Common variable immunodeficiency: a heterogeneous group needs further subclassification. Expert Rev Clin Immunol 2009, 5:629-631.

68. Ferry BL, Jones J, Bateman EA, Woodham N, Warnatz K, Schlesier M, Misbah SA, Peter HH, Chapel HM: Measurement of peripheral B cell subpopulations in common variable immunodeficiency (CVID) using a whole blood method. Clin Exp Immunol 2005, 140:532-539.

69. Kalina T, Stuchly J, Janda A, Hrusak O, Ruzickova S, Sediva A, Litzman J, Vlkova M: Profiling of polychromatic flow cytometry data on B-cells reveals patients' clusters in common variable immunodeficiency. Cytometry A 2009, 75:902-909.

70. Piqueras B, Lavenu-Bombled C, Galicier L, Bergeron-van der Cruyssen F, Mouthon L, Chevret S, Debre P, Schmitt C, Oksenhendler E: Common variable immunodeficiency patient classification based on impaired $B$ cell memory differentiation correlates with clinical aspects. J Clin Immunol 2003, 23:385-400.

71. Sanchez-Ramon S, Radigan L, Yu JE, Bard S, Cunningham-Rundles C: Memory $B$ cells in common variable immunodeficiency: clinical associations and sex differences. Clin Immunol 2008, 128:314-321.

72. Vlkova M, Fronkova E, Kanderova V, Janda A, Ruzickova S, Litzman J, Sediva A, Kalina T: Characterization of lymphocyte subsets in patients with common variable immunodeficiency reveals subsets of naive human B cells marked by CD24 expression. J Immunol 2010, 185:6431-6438

73. Wehr C, Kivioja T, Schmitt C, Ferry B, Witte T, Eren E, Vlkova M, Hernandez M, Detkova D, Bos PR, et al: The EUROclass trial: defining subgroups in common variable immunodeficiency. Blood 2008, 111:77-85.

74. Bains I, Antia R, Callard R, Yates AJ: Quantifying the development of the peripheral naive CD4+ T-cell pool in humans. Blood 2009, 113:5480-5487.

75. Cassani B, Poliani PL, Moratto D, Sobacchi C, Marrella V, Imperatori L, Vairo D, Plebani A, Giliani S, Vezzoni $P$, et al: Defect of regulatory $T$ cells in patients with Omenn syndrome. J Allergy Clin Immunol 2010, 125:209-216.

76. De Rosa SC, Herzenberg LA, Herzenberg LA, Roederer M: 11-color, 13parameter flow cytometry: identification of human naive $T$ cells by phenotype, function, and T-cell receptor diversity. Nat Med 2001, 7:245-248.

77. Gennery AR, Abinun M: Diagnosis of severe combined immunodeficiency (SCID). CPD Bulletin Immunology and Allergy 2001, 2:19-22.

78. Giovannetti A, Pierdominici M, Mazzetta F, Marziali M, Renzi C, Mileo AM, De Felice M, Mora B, Esposito A, Carello R, et al: Unravelling the complexity of $\mathrm{T}$ cell abnormalities in common variable immunodeficiency. J Immunol 2007, 178:3932-3943.

79. Holling TM, van der Stoep N, Quinten E, van den Elsen PJ: Activated human T cells accomplish MHC class II expression through T cell-specific occupation of class II transactivator promoter III. J Immunol 2002, 168:763-770.

80. Jameson SC, Masopust D: Diversity in T cell memory: an embarrassment of riches. Immunity 2009, 31:859-871.

81. Jawad AF, McDonald-Mcginn DM, Zackai E, Sullivan KE: Immunologic features of chromosome 22q11.2 deletion syndrome (DiGeorge syndrome/velocardiofacial syndrome). J Pediatr 2001, 139:715-723.

82. Kalman L, Lindegren ML, Kobrynski L, Vogt R, Hannon H, Howard JT, Buckley R: Mutations in genes required for T-cell development: IL7R, CD45, IL2RG, JAK3, RAG1, RAG2, ARTEMIS, and ADA and severe combined immunodeficiency: HuGE review. Genet Med 2004, 6:16-26.

83. Kimmig S, Przybylski GK, Schmidt CA, Laurisch K, Mowes B, Radbruch A, Thiel A: Two subsets of naive $T$ helper cells with distinct $T$ cell receptor excision circle content in human adult peripheral blood. J Exp Med 2002, 195:789-794

84. Lanzavecchia A, Sallusto F: Dynamics of T lymphocyte responses: intermediates, effectors, and memory cells. Science 2000, 290:92-97.

85. Lefrancois L, Marzo AL: The descent of memory T-cell subsets. Nat Rev Immunol 2006, 6:618-623.

86. McFarland RD, Douek DC, Koup RA, Picker LJ: Identification of a human recent thymic emigrant phenotype. Proc Natl Acad Sci USA 2000, 97:4215-4220.

87. McLean-Tooke A, Barge D, Spickett GP, Gennery AR: Immunologic defects in 22q11.2 deletion syndrome. J Allergy Clin Immunol 2008, 122:362-367, 367 e361-364.

88. Milner JD, Brenchley JM, Laurence A, Freeman AF, Hill BJ, Elias KM, Kanno Y, Spalding $\mathrm{C}$, Elloumi $\mathrm{HZ}$, Paulson $\mathrm{ML}$, et al: Impaired $\mathrm{T}(\mathrm{H}) 17$ cell differentiation in subjects with autosomal dominant hyper-lgE syndrome. Nature 2008, 452:773-776.

89. North ME, Webster AD, Farrant J: Primary defect in CD8+ lymphocytes in the antibody deficiency disease (common variable immunodeficiency): abnormalities in intracellular production of interferon-gamma (IFNgamma) in CD28+ ('cytotoxic') and CD28- ('suppressor') CD8+ subsets. Clin Exp Immunol 1998, 111:70-75.

90. Ochs HD, Gambineri E, Torgerson TR: IPEX, FOXP3 and regulatory T-cells: a model for autoimmunity. Immunol Res 2007, 38:112-121.

91. Cooper MA, Fehniger TA, Caligiuri MA: The biology of human natural killer-cell subsets. Trends Immunol 2001, 22:633-640.

92. Fan YY, Yang BY, Wu CY: Phenotypically and functionally distinct subsets of natural killer cells in human PBMCs. Cell Biol Int 2008, 32:188-197.

93. Filipovich AH, Zhang K, Snow AL, Marsh RA: X-linked lymphoproliferative syndromes: brothers or distant cousins? Blood 2010, 116:3398-3408.

94. Orange JS: Human natural killer cell deficiencies. Curr Opin Allergy Clin Immunol 2006, 6:399-409.

95. Poli A, Michel T, Theresine M, Andres E, Hentges F, Zimmer J: CD56bright natural killer (NK) cells: an important NK cell subset. Immunology 2009, 126:458-465

96. Born J, Lange T, Hansen K, Molle M, Fehm HL: Effects of sleep and circadian rhythm on human circulating immune cells. J Immunol 1997, 158:4454-4464.

97. Czesnikiewicz-Guzik M, Lee WW, Cui D, Hiruma Y, Lamar DL, Yang ZZ, Ouslander JG, Weyand CM, Goronzy JJ: T cell subset-specific susceptibility to aging. Clin Immunol 2008, 127:107-118.

98. Dimitrov S, Benedict C, Heutling D, Westermann J, Born J, Lange T: Cortisol and epinephrine control opposing circadian rhythms in T cell subsets. Blood 2009, 113:5134-5143.

99. Lee S, Kim J, Jang B, Hur S, Jung U, Kil K, Na B, Lee M, Choi Y, Fukui A, et al: Fluctuation of peripheral blood T, B, and NK cells during a menstrual cycle of normal healthy women. J Immunol 2010, 185:756-762.

100. Timmons BW, Cieslak T: Human natural killer cell subsets and acute exercise: a brief review. Exerc Immunol Rev 2008, 14:8-23.

101. Poliani PL, Vermi W, Facchetti F: Thymus microenvironment in human primary immunodeficiency diseases. Curr Opin Allergy Clin Immunol 2009, 9:489-495

102. Hazenberg MD, Verschuren MC, Hamann D, Miedema F, van Dongen JJ: T cell receptor excision circles as markers for recent thymic emigrants: basic aspects, technical approach, and guidelines for interpretation. $J$ Mol Med 2001, 79:631-640.

103. Prelog M, Keller M, Geiger R, Brandstatter A, Wurzner R, Schweigmann U, Zlamy M, Zimmerhackl LB, Grubeck-Loebenstein B: Thymectomy in early 
childhood: significant alterations of the CD4(+)CD45RA(+)CD62L(+) T cell compartment in later life. Clin Immunol 2009, 130:123-132.

104. Ribeiro RM, Perelson AS: Determining thymic output quantitatively: using models to interpret experimental T-cell receptor excision circle (TREC) data. Immunol Rev 2007, 216:21-34.

105. Arstila TP, Casrouge A, Baron V, Even J, Kanellopoulos J, Kourilsky P: A direct estimate of the human alphabeta T cell receptor diversity. Science 1999, 286:958-961

106. Brooks EG, Filipovich AH, Padgett JW, Mamlock R, Goldblum RM: T-cell receptor analysis in Omenn's syndrome: evidence for defects in gene rearrangement and assembly. Blood 1999, 93:242-250.

107. Even J, Lim A, Puisieux I, Ferradini L, Dietrich PY, Toubert A, Hercend T, Triebel F, Pannetier C, Kourilsky P: T-cell repertoires in healthy and diseased human tissues analysed by T-cell receptor beta-chain CDR3 size determination: evidence for oligoclonal expansions in tumours and inflammatory diseases. Res Immunol 1995, 146:65-80.

108. Ria F, van den Elzen P, Madakamutil LT, Miller JE, Maverakis E, Sercarz EE: Molecular characterization of the T cell repertoire using immunoscope analysis and its possible implementation in clinical practice. Curr Mol Med 2001, 1:297-304

109. Sarzotti M, Patel DD, Li X, Ozaki DA, Cao S, Langdon S, Parrott RE, Coyne K, Buckley RH: T cell repertoire development in humans with SCID after nonablative allogeneic marrow transplantation. J Immunol 2003, 170:2711-2718.

110. Stone KD, Feldman HA, Huisman C, Howlett C, Jabara HH, Bonilla FA: Analysis of in vitro lymphocyte proliferation as a screening tool for cellular immunodeficiency. Clin Immunol 2009, 131:41-49.

111. Evrard B, Dosgilbert A, Jacquemot N, Demeocq F, Gilles T, Chassagne J, Berger M, Tridon A: CFSE flow cytometric quantification of lymphocytic proliferation in extracorporeal photopheresis: use for quality control. Transfus Apher Sci 2010, 42:11-19.

112. Hawkins ED, Hommel M, Turner ML, Battye FL, Markham JF, Hodgkin PD: Measuring lymphocyte proliferation, survival and differentiation using CFSE time-series data. Nat Protoc 2007, 2:2057-2067.

113. Quah BJ, Warren HS, Parish CR: Monitoring lymphocyte proliferation in vitro and in vivo with the intracellular fluorescent dye carboxyfluorescein diacetate succinimidyl ester. Nat Protoc 2007, 2:2049-2056.

114. Last'ovicka J, Budinsky V, Spisek R, Bartunkova J: Assessment of lymphocyte proliferation: CFSE kills dividing cells and modulates expression of activation markers. Cell Immunol 2009, 256:79-85.

115. Salic A, Mitchison TJ: A chemical method for fast and sensitive detection of DNA synthesis in vivo. Proc Natl Acad Sci USA 2008, 105:2415-2420.

116. Yu Y, Arora A, Min W, Roifman CM, Grunebaum E: EdU incorporation is an alternative non-radioactive assay to $[(3) \mathrm{H}]$ thymidine uptake for in vitro measurement of mice T-cell proliferations. J Immunol Methods 2009, 350:29-35.

117. Krutzik PO, Nolan GP: Intracellular phospho-protein staining techniques for flow cytometry: monitoring single cell signaling events. Cytometry $A$ 2003, 55:61-70.

118. Schulz KR, Danna EA, Krutzik PO, Nolan GP: Single-cell phospho-protein analysis by flow cytometry. Current Protocols in Immunology 2007, 78:8.17.11-18.17.20.

119. Murray PJ: The JAK-STAT signaling pathway: input and output integration. J Immunol 2007, 178:2623-2629.

120. Shuai K, Liu B: Regulation of JAK-STAT signalling in the immune system. Nat Rev Immunol 2003, 3:900-911.

121. Bernasconi A, Marino R, Ribas A, Rossi J, Ciaccio M, Oleastro M, Ornani A, Paz R, Rivarola MA, Zelazko M, Belgorosky A: Characterization of immunodeficiency in a patient with growth hormone insensitivity secondary to a novel STAT5b gene mutation. Pediatrics 2006, 118: e1584-1592.

122. Chapgier A, Kong XF, Boisson-Dupuis S, Jouanguy E, Averbuch D, Feinberg J, Zhang SY, Bustamante J, Vogt G, Lejeune J, et al: A partial form of recessive STAT1 deficiency in humans. J Clin Invest 2009, 119:1502-1514.

123. Chapgier A, Wynn RF, Jouanguy E, Filipe-Santos O, Zhang S, Feinberg J, Hawkins K, Casanova JL, Arkwright PD: Human complete Stat-1 deficiency is associated with defective type I and II IFN responses in vitro but immunity to some low virulence viruses in vivo. J Immunol 2006, 176:5078-5083.
124. Holland SM: Interferon gamma, IL-12, IL-12R and STAT-1 immunodeficiency diseases: disorders of the interface of innate and adaptive immunity. Immunol Res 2007, 38:342-346.

125. Holland SM, DeLeo FR, Elloumi HZ, Hsu AP, Uzel G, Brodsky N, Freeman AF, Demidowich A, Davis J, Turner ML, et al: STAT3 mutations in the hyper-lgE syndrome. N Engl J Med 2007, 357:1608-1619.

126. Vidarsdottir S, Walenkamp MJ, Pereira AM, Karperien M, van Doorn J, van Duyvenvoorde HA, White S, Breuning MH, Roelfsema F, Kruithof MF, et al: Clinical and biochemical characteristics of a male patient with a novel homozygous STAT5b mutation. J Clin Endocrinol Metab 2006, 91:3482-3485.

127. Auletta JJ, Lazarus HM: Immune restoration following hematopoietic stem cell transplantation: an evolving target. Bone Marrow Transplant 2005, 35:835-857.

128. Borghans JA, Bredius RG, Hazenberg MD, Roelofs H, Jol-van der Zijde EC, Heidt J, Otto SA, Kuijpers TW, Fibbe WE, Vossen JM, et al: Early determinants of long-term T-cell reconstitution after hematopoietic stem cell transplantation for severe combined immunodeficiency. Blood 2006, 108:763-769.

129. Cuvelier GD, Schultz KR, Davis J, Hirschfeld AF, Junker AK, Tan R, Turvey SE: Optimizing outcomes of hematopoietic stem cell transplantation for severe combined immunodeficiency. Clin Immunol 2009, 131:179-188.

130. Dvorak CC, Cowan MJ: Hematopoietic stem cell transplantation for primary immunodeficiency disease. Bone Marrow Transplant 2008, 41:119-126.

131. Hakim FT, Gress RE: Reconstitution of thymic function after stem cell transplantation in humans. Curr Opin Hematol 2002, 9:490-496.

132. Komanduri KV, St John LS, de Lima M, McMannis J, Rosinski S, McNiece I, Bryan SG, Kaur I, Martin S, Wieder ED, et al: Delayed immune reconstitution after cord blood transplantation is characterized by impaired thymopoiesis and late memory T-cell skewing. Blood 2007, 110:4543-4551.

133. Seggewiss R, Einsele H: Immune reconstitution after allogeneic transplantation and expanding options for immunomodulation: an update. Blood 2010, 115:3861-3868.

134. Buckley RH, Schiff SE, Schiff RI, Markert L, Williams LW, Roberts JL, Myers LA, Ward FE: Hematopoietic stem-cell transplantation for the treatment of severe combined immunodeficiency. N Engl J Med 1999, 340:508-516.

135. Myers LA, Patel DD, Puck JM, Buckley RH: Hematopoietic stem cell transplantation for severe combined immunodeficiency in the neonatal period leads to superior thymic output and improved survival. Blood 2002, 99:872-878.

136. Railey MD, Lokhnygina Y, Buckley RH: Long-term clinical outcome of patients with severe combined immunodeficiency who received related donor bone marrow transplants without pretransplant chemotherapy or post-transplant GVHD prophylaxis. J Pediatr 2009, 155:834-840, e831.

137. Baker MW, Grossman WJ, Laessig RH, Hoffman GL, Brokopp CD, Kurtycz DF, Cogley MF, Litsheim TJ, Katcher ML, Routes JM: Development of a routine newborn screening protocol for severe combined immunodeficiency. $J$ Allergy Clin Immunol 2009, 124:522-527.

138. Baker MW, Laessig RH, Katcher ML, Routes JM, Grossman WJ, Verbsky J, Kurtycz DF, Brokopp CD: Implementing routine testing for severe combined immunodeficiency within Wisconsin's newborn screening program. Public Health Rep 2010, 125(Suppl 2):88-95.

139. Comeau AM, Hale JE, Pai SY, Bonilla FA, Notarangelo LD, Pasternack MS, Meissner HC, Cooper ER, DeMaria A, Sahai I, Eaton RB: Guidelines for implementation of population-based newborn screening for severe combined immunodeficiency. J Inherit Metab Dis 2010, 33:S273-281.

140. Gerstel-Thompson JL, Wilkey JF, Baptiste JC, Navas JS, Pai SY, Pass KA, Eaton RB, Comeau AM: High-throughput multiplexed T-cell-receptor excision circle quantitative PCR assay with internal controls for detection of severe combined immunodeficiency in population-based newborn screening. Clin Chem 2010, 56:1466-1474.

141. Lipstein EA, Vorono S, Browning MF, Green NS, Kemper AR, Knapp AA, Prosser LA, Perrin JM: Systematic evidence review of newborn screening and treatment of severe combined immunodeficiency. Pediatrics 2010 125:e1226-1235

142. Morinishi Y, Imai K, Nakagawa N, Sato H, Horiuchi K, Ohtsuka Y, Kaneda Y, Taga T, Hisakawa $H$, Miyaji R, et al: Identification of severe combined immunodeficiency by T-cell receptor excision circles quantification using neonatal guthrie cards. J Pediatr 2009, 155:829-833. 
143. Puck JM: Population-based newborn screening for severe combined immunodeficiency: steps toward implementation. J Allergy Clin Immunol 2007, 120:760-768.

144. Routes JM, Grossman WJ, Verbsky J, Laessig RH, Hoffman GL, Brokopp CD, Baker MW: Statewide newborn screening for severe T-cell lymphopenia. Jama 2009, 302:2465-2470.

145. Maecker HT, McCoy JP, Amos M, Elliott J, Gaigalas A, Wang L, Aranda R, Banchereau J, Boshoff C, Braun J, et al: A model for harmonizing flow cytometry in clinical trials. Nat Immunol 2010, 11:975-978.

146. Shankar G: Immune monitoring: it's prudent to adopt current quality regulations. Trends Biotechnol 2002, 20:495-497.

147. Shearer WT, Rosenblatt HM, Gelman RS, Oyomopito R, Plaeger S, Stiehm ER, Wara DW, Douglas SD, Luzuriaga K, McFarland EJ, et al: Lymphocyte subsets in healthy children from birth through 18 years of age: the Pediatric AIDS Clinical Trials Group P1009 study. J Allergy Clin Immunol 2003, 112:973-980

doi:10.1186/1476-7961-9-6

Cite this article as: Abraham: Relevance of laboratory testing for the diagnosis of primary immunodeficiencies: a review of case-based examples of selected immunodeficiencies. Clinical and Molecular Allergy 2011 9:6.

\section{Submit your next manuscript to BioMed Central} and take full advantage of:

- Convenient online submission

- Thorough peer review

- No space constraints or color figure charges

- Immediate publication on acceptance

- Inclusion in PubMed, CAS, Scopus and Google Scholar

- Research which is freely available for redistribution

Submit your manuscript at www.biomedcentral.com/submit 